\title{
Wet Laws, Drinking Establishments, and Violent Crime
}

\author{
D. Mark Anderson* \\ Montana State University \\ Benjamin Crost \\ University of Illinois \\ Daniel I. Rees \\ University of Colorado Denver
}

October 2014

Drawing on county-level data from Kansas for the period 1977-2011, we examine whether plausibly exogenous increases in the number of establishments licensed to sell alcohol by the drink are related to violent crime. During this period, 86 out of 105 counties in Kansas voted to legalize the sale of alcohol to the general public for on-premises consumption. We provide evidence that these counties experienced substantial increases in the total number of establishments with on-premises liquor licenses (e.g., bars and restaurants). Using legalization as an instrument, we show that issuing an on-premises liquor license is associated with 4 to 5 additional violent crimes per year. Reduced-form estimates suggest that legalizing the sale of alcohol to the general public for on-premises consumption is associated with a 10 to 25 percent increase in violent crime.

JEL Codes: H75, K42

Keywords: Alcohol, Liquor Licenses, Crime

\footnotetext{
*Corresponding author. Department of Agricultural Economics and Economics, Montana State University, P.O. Box 172920, Bozeman, MT 59717. Phone: 406-366-0921. Email: dwight.anderson@ montana.edu.

We thank Christopher Carpenter, Philip Cook, Hans Grönqvist, Susan Niknami, and seminar participants at the University of South Carolina and the $5^{\text {th }}$ Biennial Conference of the American Society of Health Economists for their comments and suggestions.
} 


\section{INTRODUCTION}

There exists a strong positive correlation between local alcohol availability, as measured by the density of bars and/or other alcohol outlets, and crime (e.g., Scribner et al. 1999; Zhu et al. 2004; Gruenewald et al. 2006; Toomey et al. 2012). The positive correlation between local alcohol availability and crime has been interpreted as evidence of causality but could be due to unobserved factors that simultaneously influence both variables. In an effort to break this simultaneity, we exploit changes in Kansas dry laws to examine whether plausibly exogenous increases in the number of establishments licensed to sell alcohol by the drink are related to violent crime.

Even after the adoption of the Twenty-first Amendment to the U.S. Constitution in 1933, the sale of alcohol for on-premises consumption was prohibited in Kansas. ${ }^{1}$ In November of 1986, Kansas voters approved a measure allowing counties to go from "dry" to "wet." This measure garnered a majority of votes in 36 out of 105 counties. As of July 1, 1987, bars and restaurants in these 36 counties were permitted to sell beer, wine, and spirits to the general public provided they derived 30 percent of their gross revenue from food sales (O`Connor 1987; Robbins 1987; St. John 2012b). Between 1987 and 2011, 50 additional counties voted to become wet; by the end of 2011, only 19 counties still prohibited by-the-drink sales of alcohol.

Below, we argue that permitting establishments to sell alcohol by the drink could, in theory, have either a positive or negative impact on violent crime. For instance, although there is

\footnotetext{
${ }^{1}$ The prohibition on the sale of alcohol for on-premises consumption appears to have been strictly enforced. Vern Miller, the attorney general of Kansas from 1970 through 1974, went so far as to raid an Amtrak train traveling through Kansas, arresting a bartender and waiter for serving alcohol to passengers (St. John 2012a). In response to this raid and a formal request from the attorney general's office, at least two commercial airlines (Continental and Frontier) stopped serving alcohol while flying over Kansas (United Press International 1973). In 1979, Attorney General Robert Stephen issued an opinion stating that "the Kansas Legislature has no authority to legislate regarding the sale or consumption of alcoholic liquor in the airspace above our state."
} 
strong evidence that consuming alcohol heightens emotional responses, impairs cognitive functioning, and reduces inhibitions (Boles and Miotto 2003; Carpenter and Dobkin 2011), bartenders, bouncers, and servers are in a position to enforce social norms against drinking to excess and even prevent arguments from escalating into violence. ${ }^{2}$

First-stage estimates based on county-level data from Kansas for the period 1977-2011 provide evidence that dry laws had the effect of limiting the number of establishments licensed to sell liquor by the drink. Second-stage estimates are much larger than those obtained from naïve Ordinary Least Squares (OLS) regressions, providing evidence that previous studies may have underestimated the impact of local alcohol availability on violent crime. With only a few exceptions (Conlin et al. 2005; Billings 2014; Chamberlain 2014), previous studies in this literature have not exploited clearly defined natural experiments.

Finally, reduced-form estimates indicate that legalizing the sale of alcohol to the general public for on-premises consumption is associated with a 10 to 25 percent increase in violent crime. Legalization is also associated with a 10 percent increase in property crime. Because we find no evidence that crime fell in dry counties when neighboring counties allowed by-the-drink sales, we conclude that bars and restaurants create criminal activity as opposed to simply displacing it. Previous studies on local alcohol availability and crime have not been able to distinguish between these competing hypotheses (Carpenter and Dobkin 2011).

\footnotetext{
${ }^{2}$ Multiple reviews have concluded that alcohol is more likely to lead to psychopharmacological violence than other substances such as marijuana; experimental studies have shown that alcohol consumption can increase the amount of pain subjects are willing to inflict upon others (Fagan 1993; Chermack and Taylor 1995; Giancoloa 2004).
} 


\section{BACKGROUND}

Dry laws take a variety of forms. For instance, they can prohibit the sale of alcohol for on-premises consumption, prohibit any and all alcohol sales, or even prohibit the possession of alcohol. Today, there are over 200 counties in the United States with some type of prohibition on alcohol sales in place (Wheeler 2012). The majority are located in the South, although a handful of counties in Kansas still prohibit by-the-drink sales to the general public, and most counties in Kansas require establishments that sell liquor for on-premises consumption to derive 30 percent of their gross revenue from food sales.

Lifting a prohibition on by-the-drink sales to the general public could increase total alcohol consumption through, in effect, allowing restaurants and bars to bundle alcohol with complementary goods and services (Guiltinan 1987; Lawless 1991). However, it could also provide an opportunity to drink in a different "social context involving a mix of circumstances, locations, [and] companions" (Lipsey et al. 1997, p. 250). In many bars and restaurants, heavy drinking is the norm; advertisements, specials, and promotions arguably lead to overindulgence (Kuo et al. 2003; Hastings et al. 2005). In other establishments, the owners, staff, and patrons actively enforce social norms against drinking to excess (Gusfield et al. 1984; Lee et al. 2008).

Regardless of its effect on total alcohol consumption, legalizing by-the-drink sales could impact crime through shifting where consumption takes place. Although previous researchers have, more often than not, argued that social interactions at bars and restaurants serve as a catalyst for violent behavior (Graham and Wells 2001; Buddie and Parks 2003; Graham and Wells 2003; Middleton et al. 2010), it is possible that verbal arguments and minor scuffles are actually less likely to escalate into fisticuffs if they take place in public. Ethnographic studies 
provide evidence that bartenders and servers view the prevention and diffusion of aggressive behavior as an important component of their jobs (Gusfield et al. 1984; Lee et al. 2008). ${ }^{3}$

By-the-drink sales could also influence the demand for other substances such as marijuana and cocaine, which could, in turn, affect crime. Consistent with the hypothesis that marijuana and alcohol are substitutes, there is evidence that marijuana participation falls sharply when individuals reach the minimum legal drinking age (Crost and Guerrero 2012), but the relationship between marijuana consumption and crime is still hotly debated (Morris et al. 2014). ${ }^{4}$ A number of previous studies have examined the relationship between alcohol and the use of illicit drugs other than marijuana (Petry 2001; Sumnall et al. 2004; Jofre-Bonet and Petry 2008; Conover and Scrimgeour 2013; Deza forthcoming), but their results have been decidedly mixed.

\subsection{Alcohol consumption and crime}

A vast literature exists on the relationship between alcohol availability and crime. ${ }^{5}$ For example, researchers have studied the effects of alcohol taxes (Cook and Moore 1993; Cook and Durrance 2013; Markowitz 2000, 2001, 2005; Markowitz and Grossman 2000; DeSimone 2001), prohibition during the 1920s and 1930s (Miron 1999; Owens 2011), the minimum legal drinking

\footnotetext{
${ }^{3}$ See also Reynolds and Harris (2006). These authors interviewed servers and managers at 21 restaurants, documenting the various tactics used to diffuse situations involving rude and potentially violent customers. Tomsen (1997), Graham et al. (2000), and Graham et al. (2005) described incidents in which bouncers and doormen clearly contributed to barroom violence. Roberts (2007) found that violence was more likely to erupt in bars that did not employ bouncers.

${ }^{4}$ Using crime data from Los Angeles, Chang and Jacobson (2014) examined the relationship between marijuana dispensary closures and crime. They found that crime increased in the immediate vicinity of dispensaries ordered to close relative to those that remained open.

${ }^{5}$ See Carpenter and Dobkin (2011) for an excellent review of this literature.
} 
age (Joksch and Jones 1993; Carpenter 2005; Carpenter and Dobkin forthcoming), underage drunk driving laws (Carpenter 2005, 2007), restrictions on weekend sales (Heaton 2012; Grönqvist and Niknami 2014), and early closing times for bars and restaurants (Chikritzhs and Stockwell 2002; Hough and Hunter 2008; Biderman et al. 2010; De Mello et al. 2013).

A separate strand of this literature has focused on the spatial relationship between establishments that sell alcohol and crime. For example, studies conducted by ecologists, criminologists, and public health experts have examined the relationship between the density of these establishments in a neighborhood (or county) and crime. However, many of these studies relied on cross-sectional variation in the density of liquor stores and/or bars. ${ }^{6}$ As a consequence, their estimates of the relationship between local alcohol availability and crime may simply reflect unobserved factors such as economic conditions. ${ }^{7}$

Considerably fewer studies have used panel data methods, exploiting openings and closings of alcohol outlets over time. ${ }^{8}$ While this approach offers cleaner identification than relying on cross-sectional variation, it still requires fairly strong identifying assumptions. For example, it implicitly assumes that bar, restaurant, and liquor store owners do not base their location decisions on future crime or its correlates.

To our knowledge, only three previous studies have exploited a clearly defined natural experiment to address the potentially endogenous relationship between local alcohol availability

\footnotetext{
${ }^{6}$ For examples of cross-sectional studies, see Scribner et al. (1995, 1999), Reid et al. (2003), Zhu et al. (2004), Britt et al. (2005), Gruenewald et al. (2006), Livingston (2008a), Liang and Chikritzhs (2011), and Toomey et al. (2012). For a more thorough review of this literature, see White et al. (forthcoming).

${ }^{7}$ Gyimah-Brempong (2001) used the number of gas stations in a census tract and median rent as instrumental variables to account for the endogeneity of alcohol outlets in the cross section. However, it is unlikely that these instruments satisfy the exclusion restriction.

${ }^{8}$ Examples of panel studies include Gruenewald and Remer (2006), Teh (2007), Livingston (2008b, 2011), and White et al. (forthcoming).
} 
and crime: Conlin et al. (2005), Chamberlain (2014) and Billings (2014). Conlin et al. (2005) and Billings (2014) used county-level data to examine the reduced-form relationship between dry laws and crime. ${ }^{9}$ Conlin et al. (2005) found that drug-related arrests fell when strict prohibitions on the sale of alcohol were lifted, but did not examine the impact of dry laws on other types of crime; Billings (2014) found that total arrests increased when strict prohibitions on the sale of alcohol were lifted. Neither Colin et al. (2005) nor Billings (2014) distinguished between counties that allowed only retail sales of alcohol and those that allowed both retail and by-thedrink sales. ${ }^{10}$

Chamberlain (2014) exploited the 2012 privatization of distilled spirits sales in Seattle to estimate the relationship between liquor store density and crime. Privatization led to a sharp expansion in local availability as large grocery and drug stores began to stock distilled spirits. He found that a one-mile reduction in the distance to the nearest liquor store was associated with a 6 to 8 percent increase in crime. The effects of privatization on violent and drug crimes were persistent, while the effects on shoplifting and other non-violent crimes appeared to be shortlived.

Like Conlin et al. (2005), Billings (2014), and Chamberlain (2014), our empirical strategy relies on a unique natural experiment. However, our focus is on establishments licensed to sell alcohol for on-premises consumption (e.g., bars and restaurants) as opposed to retailers.

\footnotetext{
${ }^{9}$ Conlin et al. (2005) used county-level data from Texas for the period 1978-1996 to examine the reduced-form relationship between dry laws and drug-related arrests. Specifically, Conlin et al. (2005) examined marijuana-related arrests, "other" illicit-drug-related arrests, drug arrests involving possession, and drug arrests involving sales/manufacturing. Billings (2014) used county-level data for the period 1994-2006 from Alabama, Kentucky, North Carolina, Tennessee, and Texas to examine the reduced-form relationship between dry laws and total arrests. Several studies have estimated the relationship between local dry laws and traffic accidents (Blose and Holder 1987; Winn and Giacopassi 1993; Baughman et al. 2001; Gary et al. 2003).

${ }^{10}$ Conlin et al. (2005) and Billing (2014) defined dry counties as those in which both retail alcohol sales and by-thedrinks sales were prohibited.
} 
By exploiting the gradual relaxation of Kansas dry laws at the county level over the period 1977-

2011, we are able to isolate arguably exogenous changes in the number of establishments

licensed to serve alcohol for on-premises consumption.

\subsection{Dry laws and liquor licenses in Kansas, 1977-2011}

Table 1 summarizes changes to the wet/dry status of Kansas counties for the period under study. ${ }^{11}$ These data were obtained through correspondence with the Kansas Division of Alcoholic Beverage Control. From 1977-1986, by-the-drink sales to the general public (including beer with an alcohol content of greater than 3.2\%) were prohibited throughout Kansas. Private clubs were exempted from this prohibition, but becoming a member required paying a $\$ 10$ fee and a 10-day wait (Stites 1985; Robbins 1986). These membership requirements, coupled with stringent licensing and record-keeping requirements, appear to have limited the number of private clubs selling liquor by the drink (Stites 1985).

On July 1, 1987, by-the-drink sales to the general public became legal in 36 counties, although establishments were required to derive 30 percent of their gross revenue from selling food (O`Connor 1987; Robbins 1987; St. John 2012b). ${ }^{12}$ Between 1987 and 2011, 13 of the

\footnotetext{
${ }^{11}$ A map of Kansas showing the year in which counties allowed by-the-drink sales is provided in the appendix (Appendix Figure 1). If by-the drink sales were allowed without the requirement that establishments derive 30 percent of their gross revenue from selling food, then the year the law went into effect is italicized.

12 These 36 counties were among the most populous in Kansas. Although the measure to legalize by-the drink sales failed in 69 counties, the state-wide vote was 59.9 percent in favor and 40.1 percent against. Under Kansas law,

A license for a drinking establishment shall allow the licensee to offer for sale, sell and serve alcoholic liquor for consumption on the licensed premises which may be open to the public..., but only if such premises are located in a county where the qualified electors of the county: (1) (A) Approved, by a majority vote of those voting thereon, the proposition to amend section 10 of article 15 of the constitution of the state of Kansas at the general election in November 1986; or (B) have approved a proposition to allow sales of alcoholic liquor by the individual drink in public places within the county at an election... (K.S.A. 2012 Supp. 41-2642).
} 
original 36 counties removed the food sales requirement. During this same period, voters approved by-the-drink sales to the general public in 50 of the 69 counties that had opted to remain dry in 1986. Eleven of these 50 counties did not impose a food sales requirement; 39 required that establishments derive 30 percent of their gross receipts from food sales. Counties that remained dry throughout the period under study are denoted with an asterisk in Table $1 .{ }^{13}$

Votes to allow by-the-drink sales or remove the food sales requirement took place in November and were officially implemented within a few days (Buckner 1992a; Associated Press 2000; Haxon 2012). ${ }^{14}$ However, because the process of obtaining a new liquor license took at least one month (Toplikar 1992; Haxon 2012; Scherer 2012), we code these laws as coming into effect on January $1^{\text {st }}$ of the following year. ${ }^{15}$

Data on liquor licenses were purchased from the Kansas Division of Alcoholic Beverage Control and include information on license type (on- versus off-premises), the location and name of the establishment that purchased the license, and the dates the license became active and inactive. ${ }^{16}$ This information was used to create a count of the number of active on-premises

As of 2013, 5 small cities in Kansas prohibited the retail sales of alcohol: Moundridge, Parkerfield, Hesston, North Newton, and Nickerson (Kansas Department of Revenue 2013).

${ }^{13}$ A brief history of Kansas liquor laws is available from the Kansas Legislative Research Department (2003). By the end of 2013, only 13 counties in Kansas prohibited on-premises sales of alcohol.

${ }^{14}$ Kansas state law requires that by-the-drink votes must be held during the November general elections (Buckner 1992a; Associated Press 2000).

${ }^{15}$ Holder and Blose (1985) found that the availability of alcohol for on-premises consumption increased gradually over a two-year period after counties in North Carolina approved by-the-drink sales.

\footnotetext{
${ }^{16}$ Approximately 12 percent of the on-premises licenses issued between 1977 and 2011 had missing inactive dates that could not be determined. When an inactive date was missing and could not be determined, we assigned an inactive date based on the average time-to-closure of establishments in the data (5 years). The results reported below are not sensitive to either dropping establishments with missing inactive dates or assuming an establishment with a missing inactive date remained open through 2011. In addition to bars, private clubs, and restaurants, the Kansas Division of Alcoholic Beverage Control issues on-premises liquor licenses to caterers, hotels, and public venues.
} 
licenses by county and year. Figure 1 provides evidence that allowing by-the-drink sales to the general public resulted in a sharp increase in the number of on-premises licenses issued by the Kansas Division of Alcoholic Beverage Control. It was constructed by regressing the number of on-premises alcohol licenses per 1,000 population in county $c$ and year $t$ on the indicator Wet $L a w$, equal to one the year in which by-the-drink sales to the general public were permitted (and is equal to zero otherwise). Five leads and 5 lags of Wet Law were also included on the righthand side of this regression as well as 104 county dummies and 34 year dummies. For now, we do not distinguish between counties that required 30 percent of gross receipts from the sale of food and those that did not.

The estimated coefficients of the 5 wet law leads are, without exception, small and statistically indistinguishable from zero. The first year in effect ("Year 0" on the horizontal axis), permitting by-the-drink sales to the general public is associated with .120 additional onpremises licenses per 1,000 population relative to the omitted period ( 6 or more years before the law change); two years later, the number of on-premises licenses per 1,000 population had increased by $.169 ; 5$ years later, the number of on-premises licenses per 1,000 population had increased by .275 . This pattern of results is consistent with the hypothesis that membership and record-keeping requirements limited the number of private clubs in operation in dry counties. ${ }^{17}$

In addition to observing the number of active on-premises licenses, we have information on the number of off-premises liquor licenses issued by the Kansas Division of Alcoholic Beverage Control. Figure 2 shows the results of regressing off-premises licenses per 1,000

\footnotetext{
${ }^{17}$ Because private clubs could only serve alcohol to members, and because becoming a member required a $\$ 10$ fee and a 10-day wait, tourists and visitors were effectively barred from consuming alcohol at a bar or restaurant in dry counties. Under Kansas law, club owners are also required to screen applicants for "good moral character" and maintain a list of all members along with their addresses. The sale of memberships must be conducted in person on club premises. Many private club owners view these restrictions as onerous and club owners often spearheaded efforts to lift the ban on by-the-drink sales (Buckner 1992b; Buckner 1992c; McKinney 2009; Haxon 2012).
} 
population in county $c$ and year $t$ on the wet law indicator, 5 leads of the wet law indicator, and 5 lags. They suggest that neither legalization nor its correlates were related to the number of establishments selling alcohol for off-premises consumption, perhaps because the retail liquor industry in Kansas is subject to tight controls (Byrne and Nizovtsev 2013).

\section{METHODS}

Yearly crime data for the period 1977-2011 come from the FBI's Uniform Crime Reports (UCR) and were made available by the Interuniversity Consortium for Political and Social Research. ${ }^{18}$ Our measure of violent crime is equal to the sum of murders, rapes, robberies and assaults that occurred within a county and year (per 1,000 population).

Below, we use within-county changes in wet/dry status to isolate exogenous variation in the number of active on-premises liquor licenses. Specifically, we estimate the following firststage equation:

$$
\text { On-Premises License } \text { Sct }=\alpha_{0}+\alpha_{1} \text { Wet Law } \text { Lat }+\boldsymbol{X}_{c t}^{\prime} \boldsymbol{\alpha}_{2}+v_{c}+z_{t}+\varepsilon_{c t},
$$

where the dependent variable, On-Premises Licenses, is equal to the number of active onpremises liquor licenses per 1,000 population in county $c$ and year $t .{ }^{19}$ Again, the indicator Wet Law is equal to one if county $c$ allowed by-the-drink sales to the general public in year $t$ (and is

\footnotetext{
${ }^{18}$ Crime data at the county level were unavailable from the UCR for the period 1993-1999. As a substitute, we turned to the Kansas Statistical Abstract, from which we obtained violent crime counts by county for the years 1993, 1994, 1997, and 1998, leaving three years of missing violent crime data. Unfortunately, the Kansas Statistical Abstract does not report violent crimes by crime type. As a consequence, estimates by type of crime are based on panels in which the years 1993 through 1999 are missing. Descriptive statistics for violent crimes by type are provided in Appendix Table 2.

${ }^{19}$ There is a one-to-one correspondence between the number of active on-premises licenses in county $c$ and year $t$ and the number of establishments permitted to sell alcohol by-the-drink.
} 
equal to zero otherwise). Counties that allowed by-the-drink sales are considered wet regardless of whether they required establishments to derive 30 of their gross receipts from food sales.

The vector $\boldsymbol{X}$ includes county-level controls for economic conditions (income per capita and the unemployment rate), population density, demographics (percent of the county population that was nonwhite, adult male, and 21 years of age and older), the ratio of Democratic to GOP votes in presidential and gubernatorial elections, and whether Sunday sales of alcohol were legal. ${ }^{20}$ Descriptive statistics and variable definitions are provided in Table 2. County and year fixed effects are represented by $v_{c}$ and $z_{t}$, respectively.

The (second-stage) relationship between violent crime and on-premises liquor licenses is given by the following equation:

$$
\text { Violent }_{\text {Crime }}^{c t}=\beta_{0}+\beta_{1} \text { On-Premises Licenses }{ }_{c t}+\boldsymbol{X}_{c t}^{\prime} \boldsymbol{\beta}_{2}+v_{c}+z_{t}+\varepsilon_{c t}
$$

where Violent Crime is equal to the number of violent crimes per 1,000 population in county $c$ and year $t$, and On-Premises Licenses is instrumented using equation (1). The vector $\boldsymbol{X}$ is composed of the observable time-varying determinants of crime listed above; county and year fixed effects are represented by $v_{c}$ and $z$, respectively. Estimates are weighted by county population and standard errors are corrected for clustering at the county level (Bertrand et al. 2004).

\footnotetext{
${ }^{20}$ Data on income per capita, the unemployment rate, and the Democratic to GOP voting ratio come from the University of Kansas's Institute for Policy and Social Research on-line data archive (http://ipsr.ku.edu/ksdata/). Population data come from the U.S. Census. The Kansas Department of Revenue provided the authors with a list of municipalities that currently allow Sunday sales of alcohol for off-premises consumption. For these municipalities, a date of legalization was acquired by searching municipal codes, local newspapers, and town council minutes, or contacting municipal clerks directly. The Sunday sales indicator is equal to one if Sunday sales for off-premises consumption were allowed in any municipality in county $c$ and year $t$ (and is equal to zero otherwise).
} 
When interpreting the second-stage estimates, it is important to keep in mind that $\beta_{1}$ represents a local average treatment effect. As noted above, because private clubs were exempt from county-level prohibitions on selling alcohol by the drink, on-premises liquor licenses were issued to these establishments in ostensibly dry counties. However, after counties went wet, very few new private clubs opened. ${ }^{21}$ Our estimate of $\beta_{1}$ should, therefore, be thought of as the effect of opening a bar or restaurant, as opposed to a private club, on violent crime. ${ }^{22}$

The instrumental variables strategy outlined above is based on the assumption that the adoption of wet laws affected violent crime only through the number of establishments with onpremises liquor licenses. It is possible, however, that allowing by-the-drink sales had an impact on violent crime through the number of off-premises licenses issued by the Kansas Division of Alcoholic Beverage Control, which would be a violation of the exclusion restriction. Below, we present estimates of the relationship between wet laws and active off-premises liquor licenses in county $c$ and year $t$. Consistent with the trends shown in Figure 2, they suggest that allowing bythe-drink sales had no effect on the number of liquor retailers in operation.

It is also possible that changes in wet/dry status had a direct effect on the demand for alcohol at the county level, perhaps by removing or lessening the social stigma attached to binge drinking. ${ }^{23}$ If this were the case, then estimates of $\beta_{1}$ would be biased, but a reduced-form

\footnotetext{
${ }^{21}$ A number of private clubs converted to restaurants or bars (Buckner 1992b; Toplikar 1992; McKinney 2009; Haxon 2012). At least one club became a restaurant shortly after voters allowed by-the-drink sales to the general public but converted back to its original status because it had trouble meeting the requirement that 30 percent of receipts be derived from the sale of food (Toplikar 1992). In 1986 there were approximately 550 private clubs operating in Kansas (or .230 per 1,000 population); by 2011, this number had fallen to approximately 420 (or .150 per 1,000 population).

${ }^{22}$ Note that because the dependent variable and independent variable of interest are both divided by population in equation (2), $\beta_{1}=\partial($ Violent Crime $) / \partial($ On-Premises Licenses $)$.

${ }^{23}$ Unfortunately, we do not have access to data on alcohol consumption at the county level. Appendix Figure 2 shows state-level trends in total alcohol consumption for the period 1977-2011. After July 1, 1987, when Kansas counties had the option of allowing on-premises consumption, there is a modest upward trend in total alcohol
} 
approach could still be used to estimate the overall effect on violent crime of going from dry to wet. Below, we present estimates of the following reduced-form equation:

$$
\text { Violent Crime }_{c t}=\pi_{0}+\pi_{1} \text { Wet Law } \text { Lat }_{c}+\boldsymbol{X}_{c t}^{\prime} \boldsymbol{\pi}_{2}+v_{c}+z_{t}+\varepsilon_{c t},
$$

where the variables are defined as above. ${ }^{24}$ Under the parallel-trends assumption, the estimate of $\pi_{l}$ represents the effect of allowing by-the-drinks sales on the number of violent crimes per 1,000 population. Again, estimates are weighted by county population and standard errors are corrected for clustering at the county level (Bertrand et al. 2004).

\section{RESULTS}

\subsection{Instrumental variables estimates}

Table 2 presents summary statistics of the variables used in the analysis. On average, there were .813 active licenses per 1,000 population in wet counties. In contrast, there were only .295 on-premises licenses per 1,000 population in dry counties. Wet counties also experienced higher rates of violent crime (4.28 per 1,000 population) as compared to dry counties (3.05 per 1,000 population).

Estimates of the first-stage relationship between Wet Law and the number of active onpremises liquor licenses are reported in Table 3 and are consistent with the trends shown in Figure 1. Without controlling for county-specific linear time trends, allowing by-the-drink sales to the general public is associated with a .177 increase in the number of on-premises licenses per

consumption. However, this trend is also evident in neighboring states, suggesting that it was not caused by changes in Kansas wet laws.

${ }^{24}$ Colin et al. (2005) and Billings (2014) used this specification to estimate the relationship between dry laws and arrests. Using data from São Paulo, Biderman et al. (2010) used a similar specification to estimate the relationship between laws restricting how late bars and restaurants could stay open and homicides. 
1,000 population. When county-specific linear time trends are included on the right-hand side, this estimate decreases slightly in magnitude: allowing by-the-drink sales is associated with a .143 increase in the number of on-premises licenses per 1,000 population. Both of these estimates are statistically significant at conventional levels and easily meet the Staiger and Stock (1997) criterion. ${ }^{25}$

Estimates of the relationship between allowing by-the-drink sales and the number of active off-premises liquor licenses in county $c$ and year $t$ are presented in Appendix Table 1. These estimates are consistent with the trends shown in Figure 2. Specifically, the coefficient of the wet law indicator is small and statistically insignificant with or without controlling for county-specific linear trends.

Table 4 presents estimates of the relationship between on-premises liquor licenses and violent crime. The first two columns present OLS estimates of this relationship while the last two columns present two stage least squares (2SLS) estimates. The OLS estimates suggest that issuing an on-premises liquor license is associated with .853 to 1.24 additional violent crimes per year. Both of these estimates are statistically significant at the 10 percent level. The 2SLS estimates suggest that issuing an on-premises liquor license results in 4.31 to 5.00 additional violent crimes per year. Without county-specific linear time trends, the 2SLS estimate is statistically significant at the 5 percent level; controlling for county-specific trends, the 2SLS estimate is statistically significant at the 1 percent level.

There are at least two plausible explanations for why the 2SLS estimates are larger than the OLS estimates. First, it is possible that establishments (bars, clubs, and restaurants) opened

\footnotetext{
${ }^{25}$ The test of whether the coefficient of Wet Law is equal to zero yields an F-statistic of 51.9 when county-specific linear trends are not included as controls. The F-statistic is 41.9 when county-specific linear trends are included.
} 
because their owners anticipated that economic conditions would improve and crime rates would go down. Instrumenting using Wet Law avoids this potential source of endogeneity. Alternatively, it is possible that, on average, opening a bar or restaurant has a larger effect on crime than opening a private club, perhaps because private clubs attract less rowdy patrons or because Kansas state law requires that applicants be "screened by the club for good moral character." Because so few new licenses were issued to private clubs once voters opted to allow by-the-drink sales to the general public, the 2SLS estimates in Table 4 should be thought of as reflecting the effect of opening a bar or restaurant.

Table 5 shows 2SLS estimates disaggregated by type of violent crime. The sample sizes in Table 5 are smaller than in previous tables $(2,932$ versus 3,352$)$ because crime data at the county level were unavailable from the UCR for the period 1993-1999 and the Kansas Statistical Abstract, our alternative source of data, does not report violent crimes disaggregated by type.

Despite the reduction in sample size, 2SLS estimates of the effect of on-premises licenses on the total number of violent crimes are similar to those reported in Table 4. The regressions with county-specific linear time trends suggest that issuing an on-premises liquor license leads to an additional .421 rapes, 2.53 robberies and 2.39 assaults per year. The estimates for rape and robbery are statistically significant at the 5 percent level, while the estimate for assault is statistically insignificant $(\mathrm{p}$-value $=.143)$. The estimated relationship between on-premises liquor licenses and murders is relatively small and statistically insignificant.

\subsection{Reduced-form estimates}

Table 6 presents reduced-form estimates of the relationship between wet/dry status and violent crime. The advantage of the reduced-form approach is that it does not rely on excluding 
the wet law indicator from a second-stage equation. Baseline estimates in the first two columns of Table 6 suggest that allowing by-the-drink sales resulted in .714 to .761 additional violent crimes per 1,000 population, or a 23 to 25 percent increase relative to the mean of 3.05 violent crimes per 1,000 population in dry counties. ${ }^{26}$

The remaining columns in Table 6 present estimates of equation (3) that include leads and lags of the wet indicator. Consistent with the parallel trends assumption, there is little evidence that the violent crime rate increased in the years leading up to legalization. The estimated effect of allowing by-the-drink sales is not significant until after two years; after five or more years, allowing by-the-drink sales is associated with a .606 to .804 increase in the number of violent crimes per 1,000 population.

We report reduced-form estimates disaggregated by type of violent crime in Table 7 . The results are qualitatively similar to those in Table 5. The regressions with county-specific time trends suggest that allowing on-premises alcohol consumption is associated with .065 additional rapes per 1,000 population, .393 additional robberies, and .372 additional assaults. The estimates for rape and robbery are statistically significant at the 5 percent level, while the estimate for assault is not statistically significant at conventional levels ( $\mathrm{p}$-value $=.15$ ). The estimated relationship between wet laws and murder is relatively small and statistically insignificant.

We report the results of various robustness checks in Table 8. The estimate in the first column comes from a series of regressions (i.e., trials) in which placebo Wet Law indicators were randomly assigned. Because 86 counties in Kansas legalized by-the-drink sales during the

\footnotetext{
${ }^{26}$ We also experimented with using the wild cluster bootstrap method suggested by Cameron et al. (2008) to calculate standard errors and t-statistics. Wild cluster bootstrap critical values provide an asymptotic refinement and may work better than other inference methods for OLS when the number of clusters is small. The results reported in Table 6 were robust to using the wild cluster bootstrap method to calculate standard errors and t-statistics.
} 
period 1986-2011, 86 placebo indicators were assigned per trial. The estimated coefficient of the placebo indicator was positive in 51 out of 100 trials, and positive and significant at the 5 percent level only twice. The mean of the placebo coefficients is equal to -.022 . This exercise illustrates that our results cannot be easily reproduced by randomly generating the variable of interest.

Lott and Whitley (2003) noted that rural counties with relatively small populations in the UCR underreport crime at higher rates than do larger counties. In columns (2) and (3) we restrict our attention to counties with a population greater than 5,000 and 10,000 residents, respectively. The estimate in column (2) is similar to those reported in Table 6, while the estimate in column (3) is slightly larger in magnitude. Specifically, when the sample is restricted to counties with a population greater than 10,000 , allowing by-the-drink sales is associated with .895 more violent crimes per 1,000 population.

In column (4) we control for county-specific quadratic time trends. Again, the estimate is positive, large in magnitude, and statistically significant at conventional levels. Specifically, allowing by-the-drink sales is associated with .926 more violent crimes per 1,000 population, a 30.4 percent increase in violent crime relative to the pre-treatment mean of 3.05 .

The crack epidemic began in 1986, shortly before by-the-drink sales became legal in 36 Kansas counties, and appears to have peaked in the mid-1990s (Cooper 2002; Fryer et al. 2013). In an effort to account for the effect of the crack epidemic on violent crime in Kansas City (and, to a lesser extent, its effect on violent crime in Topeka and Wichita), we include a control based on the crack index developed by Fryer et al. (2013). ${ }^{27}$ The results are reported in column (5) of

\footnotetext{
27 The Fryer et al. (2013) crack index is at the city level and was calculated using data on cocaine arrests and seizures, emergency room visits involving cocaine, and newspaper reports that mentioned crack. It is available for Kansas City (Johnson County and Wyandotte County), Topeka (Shawnee County) and Wichita (Sedgwick County) for the years 1985, 1989, 1993, 1997, and 2000. We used linear interpolation to calculate values of the index for the years 1986-1988, 1990-1992, 1994-1996, 1998-1999, and 2001-2003. Our control for the crack epidemic takes on the value of 0 for all other counties and years.
} 
Table 8. Controlling for the crack epidemic does not have an appreciable impact on our estimate of $\pi_{l}$. Specifically, the legalization of by-the-drink sales is associated with a .769 increase in violent crimes per 1,000 population.

In column (6) of Table 8, we replace the violent crime rate with its natural log, and in column (7) we estimate the effect of allowing by-the-drink sales using a negative binomial regression model. ${ }^{28}$ These modifications produce smaller estimates than those reported in Table 6. Specifically, when the log transformation is used, allowing by-the-drink sales is associated with a $10.7\left(\mathrm{e}^{102}-1=.107\right)$ percent increase in violent crime. When violent crime is modeled as a count process, allowing by-the-drink sales is associated with a $12.4\left(\mathrm{e}^{.117}-1=.124\right)$ percent increase. ${ }^{29}$

Changes in policing effort in response to the legalization of by-the-drink sales represent a potential source of omitted variable bias. If police departments and Sheriff's Offices hired extra officers after legalization, then the true relationship between Wet Law and violent crime could, in fact, be larger than the estimates of $\pi_{l}$ reported above. To explore this issue, we regressed the number of sworn officers employed in county $c$ and year $t$ on the wet law indicator and the controls used in previous analyses. ${ }^{30}$ The estimates are reported in Table 9. Allowing by-the-

\footnotetext{
${ }^{28}$ Because Violent Crime is equal to 0 for 310 of the 3,352 county-year observations in our data, we followed Wooldridge (2013, pp. 193-194) by specifying the dependent variable as $\ln ($ Violent Crime +1$)$ in column (5). On average, there were 93.6 violent crimes committed per county-year.

${ }^{29}$ Allowing by-the-drink sales is associated with a 15.1 percent increase in violent crime when county-specific linear time trends are excluded from the negative binomial model. The negative binomial model was used instead of the Poisson because we found strong evidence of overdispersion in the data. Greene (2007) noted that the negative binomial model with fixed effects may suffer from the incidental parameters problem. However, in a simulation study, Allison and Waterman (2002) found little evidence of the incidental parameters problem when estimating an unconditional negative binomial regression with fixed effects.

${ }^{30}$ Law enforcement employment data are from the annual report Crime in the United States, published by the Federal Bureau of Investigation. Because these data are available only for the period 1995-2011, the sample size in Table 9 is reduced to approximately 1,700.
} 
drink sales is associated with a (statistically insignificant) .033 decrease in the number of officers employed by sheriffs' offices per 1,000 population and a (statistically insignificant) .037 decrease in the number of officers employed by police departments per 1,000 population. In comparison, the mean number of officers employed by sheriffs' offices was .718 per 1,000 population, and the mean number of officers employed by police departments was 1.40 per 1,000 population.

As a final robustness test, we examine whether economic conditions or broad changes in social mores, as measured by voting patterns in congressional and gubernatorial elections, can predict the legal status of by-the-drink sales (Table 10). Specifically, we regress the wet law indicator on income per capita, the unemployment rate, the ratio of Democratic to GOP votes, and the full set of controls. Point estimates from this exercise are small and statistically insignificant, suggesting that the post-legalization increase in violent crime documented in Tables 6-8 was not driven by economic conditions or the adoption of more liberal attitudes with regard to issues aside from the on-premises consumption of alcohol. ${ }^{31}$

\subsection{Distinguishing between wet laws based on whether food sales were required}

By the end of 2011, 24 out of the 86 wet counties in Kansas did not require food sales. The remaining 62 wet counties required that establishments derive 30 percent of their gross receipts from food sales (Table 1). Up to this point in the analysis, we have not distinguished between wet counties based on whether they had a food sales requirement.

In Table 11, we report estimates of equation (3) in which Wet Law is replaced by two mutually exclusive indicators: Wet Law with Food Sales $30 \%$ Gross is equal to one if county $c$

\footnotetext{
31 We also explored this issue using a discrete-time hazard model. The results provided little evidence that voting patterns were related to the likelihood of legalizing by-the-drink sales.
} 
required establishments that served alcohol to derive 30 percent of their gross revenue from food sales (and is equal to zero otherwise); Wet Law with Food Sales Not Required is equal to one if county $c$ did not require these establishments to derive 30 percent of their gross revenue from food sales (and is equal to zero otherwise).

The estimates in Table 11 provide some evidence that the food sales requirement dampened the effect of by-the-drink sales on violent crime: without controlling for countyspecific linear time trends, the estimated coefficient of Wet Laws with Food Sales 30\% Gross is .686 while the estimated coefficient of Wet Laws with Food Sales Not Required is 1.26. We cannot, however, reject the hypothesis that these estimates are equal. Likewise, when we control for county-specific linear trends, the estimated coefficient on Wet Laws with Food Sales $30 \%$ Gross is smaller than the estimated coefficient on Wet Laws with Food Sales Not Required, but the difference is not statistically significant.

\subsection{Spillovers across county borders}

The issue of displacement is not typically addressed by studies on local alcohol availability and crime (Carpenter and Dobkin 2011). ${ }^{32}$ In the context of the present study, the positive relationship between allowing by-the-drink sales and violent crime could, in theory, reflect a net increase in criminal activity; alternatively, it could be the case that violence-prone residents of neighboring counties drove across the border after establishments began selling alcohol to the general public for on-premises consumption.

\footnotetext{
${ }^{32}$ Chamberlain (2014) is one of the few studies to address this issue. He found evidence that reductions in the distance to the nearest liquor store created violent and drug-related crimes. In contrast, increases in shoplifting and non-violent crimes were found to be, at least in part, due to displacement.
} 
In an effort to distinguish between these hypotheses, we included an additional variable on the right-hand side of equation (3) equal to the number of wet counties bordering county $c$ in year $t .{ }^{33}$ The results are reported in the first column of Table 12 . When this additional variable is included on the right-hand side of equation (3), the estimated coefficient of Wet Law is essentially unchanged. More importantly, the estimated relationship between violent crime and the number of wet counties bordering county $c$ in year $t$ is small, positive, and statistically insignificant, suggesting that crime was not displaced (i.e., shifted across county lines) when a neighboring county legalized by-the-drink sales to the general public.

Including mutually exclusive indicators for having one wet county as a neighbor or having two or more wet counties as neighbors produces qualitatively similar estimates to those reported in column (1). Likewise, when the sample is restricted to counties that remained dry throughout the period 1977-2011, we find little evidence to suggest that residents of these counties traveled across the border and committed violent crimes that would have otherwise been committed nearer to home. ${ }^{34}$

In columns (5) and (6) of Table 12, we distinguish between neighboring wet counties based on whether they had a food sales requirement. Specifically, we included two new variables in the model: the first is equal the number of wet counties sharing a border with county $c$ that required establishments to derive 30 percent of their gross revenue from food sales; the second is equal to the number of wet counties sharing a border with county $c$ that did not require

\footnotetext{
${ }^{33}$ Wet counties in Colorado, Nebraska, Missouri and Oklahoma that were on the Kansas state border were included in this count. Four counties in Oklahoma (Beaver, Cimarron, Grant, and Harper) were coded as dry.

${ }^{34}$ The 19 counties in Kansas that remained dry throughout the period under study are denoted with an asterisk in Table 1. These counties were typically less populous than the counties with which they shared a border and experienced lower levels of violent crime. During the period under study, always-dry counties had a mean population of 5,443 and experienced an average of 1.15 violent crimes per year, while Kansas counties on their border had a mean population of 15,025 and experienced an average of 2.01 violent crimes per year.
} 
establishments to sell food. Including these new variables on the right-hand side of equation (3) provides little evidence that crime went down when residents had the option of crossing county lines to buy liquor by the drink.

\subsection{Property crime}

In Table 13 we explore the relationship between legalizing by-the-drink sales on property crimes, defined as burglaries, larcenies, and motor vehicle thefts. The first two columns of Table 13 present 2SLS estimates of the effect of issuing a liquor license; the third and fourth columns present reduced-form estimates of the effect of allowing by-the-drink sales.

Without controlling for county-specific linear trends these estimates, although large and positive, are not significant at conventional levels. However, when we include county-specific linear trends, they become statistically significant. Issuing a liquor license is associated with 26.6 additional property crimes per year; counties that allowed by-the-drink sales experienced an average of 3.81 additional property crimes per 1,000 population per year. This latter estimate represents a 9.8 percent increase relative to the mean of 38.8 property crimes per 1,000 population in dry counties. ${ }^{35}$

In Table 14, we explore the relationship between allowing by-the-drink sales and property crimes by type. Controlling for county-specific linear trends, the legalization of by-thedrink sales is associated with 3.40 larcenies per 1,000 population and .859 motor vehicle thefts.

\footnotetext{
35 Appendix Table 3 reports robustness checks. When property crime is modeled as a count process, allowing bythe-drink sales is associated with a 9.5 percent $\left(\mathrm{e}^{.091}-1=.095\right)$ percent increase in the number of property crimes reported in county $c$ and year $t$.
} 
The estimated relationship between burglaries and legalization, although positive, is not statistically significant. $^{36}$

The issue of displacement is revisited in Table 15. The results are not consistent with the hypothesis that property crime was shifted across county lines when a neighboring county legalized by-the-drink sales to the general public. In fact, the estimated effect of having a wet county on the border is positive and significant in the full sample.

\section{CONCLUSION}

While a large number of studies have found a positive association between local alcohol availability and crime, these studies have generally treated the location decisions of bar and liquor store owners as exogenous. In contrast, we exploit a unique natural experiment to address the potential endogeneity of local alcohol availability. Specifically, using county-level data from Kansas for the period 1977-2011, we examine whether arguably exogenous increases in the number of establishments licensed to sell alcohol by the drink are related to violent crime. During this period, 86 out of 105 counties voted to go from "dry" to "wet" by legalizing the sale of alcohol to the general public for on-premises consumption.

Using these changes in wet/dry status to instrument for the number of establishments licensed to sell alcohol by the drink, we find that issuing an on-premises liquor license is associated with 4.31 to 5.00 additional violent crimes per year. Approximately half of these additional crimes appear to be robberies. Issuing an on-premises license is also associated with more rapes and, in specifications without county-specific linear time trends, more assaults.

\footnotetext{
${ }^{36}$ Appendix Table 4 shows 2SLS estimates of the relationship between on-premises licenses and property crime by type. Issuing an on-premises liquor license is associated with 21.9 additional larcenies and 5.21 additional motor vehicle thefts.
} 
Of course, these IV estimates are based on the assumption that changes in the wet/dry status of counties influence crime only through the number of establishments with on-premises liquor licenses, which may have been violated in practice. For instance, it is possible that these changes could have had a direct effect on the overall demand for both on- and off-premises alcohol consumption, perhaps by lessening the social stigma attached to drinking. Reduced-form estimates, which are not based on the assumption that wet laws worked only through drinking establishments, suggest that allowing by-the-drink sales is associated with a 10 to 25 percent increase in violent crime and a 10 percent increase in property crime. Because we find no evidence that crime fell in dry counties when their neighbors allowed by-the-drink sales, we conclude that bars and restaurants create criminal activity as opposed to simply encouraging violence-prone residents to cross county lines.

To our knowledge, these results are the first to directly link alcohol sales for on-premises consumption to an increase in criminal activity. There are at least three potential mechanisms that could explain this relationship. First, it could be due to increased consumption of alcohol, which has been linked to crime by an extensive literature. Second, the increase in crime may be the result of a shift in alcohol consumption from private homes to public venues such as bars and restaurants. This latter explanation is consistent with previous evidence that alcohol consumption in public serves as a catalyst for violent behavior (Graham and Wells 2001; Buddie and Parks 2003; Graham and Wells 2003; Middleton et al. 2010), but could also affect which crimes are actually reported. If, for example, an assault that takes place at home is less likely to be reported than an assault that takes place in public, then our estimates could overstate the true impact of by-the-drink sales on violent crime. Finally, more crime may be the result of an increase in late night foot traffic in areas around bars and restaurants, which could have increased 
the number of potential crime victims. While we cannot distinguish between these mechanisms, our results provide evidence that restrictions on local alcohol availability can play an important role in crime prevention.

\section{REFERENCES}

Allison, Paul and Richard Waterman. 2002. "Fixed-Effects Negative Binomial Regression Models." Sociological Methodology, Vol. 32, No. 1, pp. 247-265.

Associated Press. 2000. “Kansas County's Liquor Election is Primary Issue.” Lawrence JournalWorld, August 9. Available at: http://www2.ljworld.com/news/2000/aug/09/kansas_countys_liquor/.

Baughman, Reagan, Michael Conlin, Stacey Dickert-Conlin, and John Pepper. 2001. "Slippery When Wet: The Effects of Local Alcohol Access Laws on Highway Safety." Journal of Health Economics, Vol. 20, No. 6, pp. 1089-1096.

Bertrand, Marianne, Esther Duflo, and Sendhil Mullainathan. 2004. "How Much Should We Trust Differences-in-Differences Estimates?" Quarterly Journal of Economics, Vol. 119, No. 1, pp. 249-276.

Biderman, Ciro, João M. P. De Mello, and Alexandre Schneider. 2010. "Dry Laws and Homicides: Evidence from the São Paolo Metropolitan Area.” Economic Journal, Vol. 120, No. 543, pp. 157-182.

Billings, Stephen. 2014. "Local Option, Alcohol and Crime." B.E. Journal of Economic Analysis and Policy (Contributions), Vol. 14, No. 3, pp. 791-816.

Blose, James and Harold Holder. 1987. "Liquor-by-the-Drink and Alcohol-Related Traffic Crashes: A Natural Experiment Using Time-Series Analysis." Journal of Studies on Alcohol, Vol. 48, No. 1, pp. 52-60.

Boles, Sharon M. and Karen Miotto 2003. "Substance Abuse and Violence: A Review of the Literature." Aggression and Violent Behavior, Vol. 8, No. 2, pp. 155-174.

Britt, Heather, Bradley Carlin, Traci Toomey, and Alexander Wagenaar. 2005. "Neighborhood Level Spatial Analysis of the Relationship between Alcohol Outlet Density and Criminal Violence." Environmental and Ecological Statistics, Vol. 12, No. 4, pp. 411-426.

Buddie, Amy and Kathleen Parks. 2003. "The Role of the Bar Context and Social Behaviors on Women's Risk for Aggression.” Journal of Interpersonal Violence, Vol. 18, No. 12, pp. 1378-1393. 
Buckner, Steve. 1992a. "Voters Sound Taps on Liquor-by-Drink Food Requirement." Lawrence Journal-World, November 4. Available at: http://www2.ljworld.com/news/1992/nov/04/voters_sound_taps_on/.

Buckner, Steve. 1992b. "Club Owner Seeks Countywide Vote of Liquor by Drink." Lawrence Journal-World, June 30. Available at: http://www2.ljworld.com/news/1992/jun/30/club_owner_seeks_countywide/.

Buckner, Steve. 1992c. "Club Owners Favor Liquor Change.” Lawrence Journal-World, October 28. Available at: http://www2.ljworld.com/news/1992/oct/28/club owners favor liquor/.

Byrne, Paul F. and Dmitri Nizovtsev. 2013. "Exploring the Effects of Cross-state Differences in Liquor Retail Restrictions.” Working paper, School of Business, Washburn University.

Cameron, Colin, Jonah Gelbach, and Douglas Miller. 2008. "Bootstrap-Based Improvements for Inference with Clustered Errors." Review of Economics and Statistics, Vol. 90, No. 3, pp. 414-427.

Carpenter, Christopher. 2005. "Heavy Alcohol Use and Commission of Nuisance Crime: Evidence from Underage Drunk Driving Laws." American Economic Review Papers and Proceedings, Vol. 95, No. 2, pp. 267-272.

Carpenter, Christopher. 2007. "Heavy Alcohol Use and Crime: Evidence from Underage Drunk Driving Laws,” Journal of Law and Economics, Vol. 50, No. 3, pp. 539-557.

Carpenter, Christopher and Carlos Dobkin. 2011. "Alcohol Regulation and Crime." In Philip Cook, Jens Ludwig, and Justin McCrary, eds., Controlling Crime: Strategies and Tradeoffs. Chicago, IL: University of Chicago Press.

Carpenter, Christopher and Carlos Dobkin. Forthcoming. "The Minimum Legal Drinking Age and Crime." Review of Economics and Statistics.

Chamberlain, Andrew. 2014. "Urban Crime and Spatial Proximity to Liquor: Evidence from a Quasi-Experiment in Seattle." Working Paper, Department of Economics, University of California, San Diego.

Chang, Tom and Mireille Jacobson. 2014. "Going to Pot? The Impact of Dispensary Closures on Crime.” Working Paper, Marshall School of Business, University of Southern California.

Chermack, Stephen and Stuart Taylor. 1995. "Alcohol and Human Physical Aggression: Pharmacological versus Expectancy Effects." Journal of Studies on Alcohol and Drugs, Vol. 56, No. 4, pp. 449-456.

Chikritzhs, Tanya and Tim Stockwell. 2002. “The Impact of Later Trading Hours for 
Australian Public Houses (Hotels) on Levels of Violence." Journal of Studies on Alcohol, Vol. 63, No. 5, pp. 591-599.

Conlin, Michael, Stacey Dickert-Conlin, and John Pepper. 2005. "The Effect of Alcohol Prohibition on Illicit Drug-Related Crimes." Journal of Law and Economics, Vol. 48, No. 1, pp. 215-234.

Conover, Emily and Dean Scrimgeour. 2013. "Health Consequences of Easier Access to Alcohol: New Zealand Evidence." Journal of Health Economics, Vol. 32, No. 3, pp. 570585.

Cook, Philip and Michael Moore. 1993. "Violence Reduction through Restrictions on Alcohol Availability." Alcohol Health and Research World, Vol. 17, No. 2, pp. 151-157.

Cook, Philip and Christine Piette Durrance. 2013. "The Virtuous Tax: Lifesaving and CrimePrevention Effects of the 1991 Federal Alcohol-Tax Increase." Journal of Health Economics, Vol. 32, No. 1, pp. 261-267.

Cooper, Edith Fairman. 2002. The Emergence of Crack Cocaine Abuse. Hauppauge, NY: Nova Science Publishers, Inc.

Crost, Benjamin and Santiago Guerrero. 2012. "The Effect Alcohol Availability on Marijuana Use: Evidence from the Minimum Legal Drinking Age." Journal of Health Economics, Vol. 31, No. 1, pp. 112-121.

De Mello, João M. P., Daniel Mejia, and Lucia Suarez. 2013. "The Pharmacological Channel Revisted: Alcohol Sales Restrictions and Crime in Bogota.” Working Paper, Department of Economics, Universidad de los Andes.

DeSimone, Jeffrey. 2001. "The Effect of Cocaine Prices on Crime.” Economic Inquiry, Vol. 39, No. 4, pp. 627-643.

Deza, Monica. Forthcoming. "The Effects of Alcohol on the Consumption of Hard Drugs: Regression Discontinuity Evidence from the National Longitudinal Study of Youth, 1997." Health Economics.

Fagan, Jeffrey. 1993. "Interactions among Drugs, Alcohol, and Violence." Health Affairs, Vol. 12, No. 4, pp. 65-79.

Fryer, Jr., Roland, Paul Heaton, Steven Levitt, and Kevin Murphy. 2013. "Measuring Crack Cocaine and Its Impact." Economic Inquiry, Vol. 51, No., 3, pp. 1651-1681.

Gary, Sarah Lynn Schulte, Lisa Aultman-Hall, Matt McCourt, and Nick Stamatiadis. 2003. "Consideration of Driver Home County Prohibition and Alcohol-Related Vehicle Crashes." Accident Analysis and Prevention, Vol. 35, No. 5, pp. 641-648. 
Giancoloa, Peter. 2004. "Executive Functioning and Alcohol-Related Aggression." Journal of Abnormal Psychology, Vol. 113, No. 4, pp. 541-555.

Graham, Kathryn, Sharon Bernards, D. Wayne Osgood, Ross Homel, and John Purcell. 2005. "Guardians and Handlers: The Role of Bar Staff in Preventing and Managing Aggression.” Addiction, Vol. 100, No. 6, pp. 755-766.

Graham, Kathryn and Samantha Wells. 2001. "Aggression among Young adults in the Social Context of the Bar." Addiction Research, Vol. 9, No. 3, pp. 193-219.

Graham, Kathryn and Samantha Wells. 2003. “'Somebody's Gonna Get Their Head Kicked in Tonight!' Aggression Among Young Males in Bars - A Question of Values?" British Journal of Criminology, Vol., 43, No. 3, pp. 546-566.

Graham, Kathryn, Paulette West, and Samantha Wells. 2000. "Evaluating Theories of AlcoholRelated Aggression Using Observations of Young Adults in Bars." Addiction, Vol. 95, No. 6, pp. 847-863.

Greene, William. 2007. "Fixed and Random Effects Models for Count Data." Working Paper, Department of Economics, New York University.

Grönqvist, Hans and Susan Niknami. 2014. "Alcohol Availability and Crime: Lessons from Liberalized Weekend Sales Restrictions." Journal of Urban Economics, Vol. 81, No. 3, pp. 77-84.

Gruenewald, Paul and Lillian Remer. 2006. "Changes in Outlet Densities Affect Violence Rates." Alcoholism: Clinical and Experimental Research, Vol. 30, No. 7, pp. 1184-1193.

Gruenewald, Paul, Bridget Freisthler, Lillian Remer, Elizabeth LaScala, and Andrew Treno. 2006. "Ecological Models of Alcohol Outlets and Violent Assaults: Crime Potentials and Geospatial Analysis." Addiction, Vol. 101, No. 5, pp. 666-677.

Guiltinan, Joseph. 1987. "The Price Bundling of Services: A Normative Framework." Journal of Marketing, Vol. 51, No. 2, pp. 74-85.

Gusfield, Joseph, Paul Rasmussen, and Joseph Kotarba. 1984. "The Social Control of DrinkingDriving: An Ethnographic Study of Bar Settings." Law and Policy, Vol., 6, No. 1, pp. 45-66.

Gyimah-Brempong, Kwabena. 2001. "Alcohol Availability and Crime: Evidence from Census Tract Data." Southern Economic Journal, Vol. 68, No. 1, pp. 2-21.

Hastings, Gerard, Susan Anderson, Emma Cooke, and Ross Gordon. 2005. "Alcohol Marketing and Young People's Drinking: A Review of the Research." Journal of Public Health Policy, Vol. 26, No. 3, pp. 296-311. 
Haxon, Rod. 2012. "Voters Okay Liquor-by-the-Drink." The Scott County Record, November 5. Available at:

http://www.scottcountyrecord.com/news/voters-okay-liquor-by-the-drink.

Heaton, Paul. 2012. "Sunday Liquor Laws and Crime.” Journal of Public Economics, Vol. 96, No. 1-2, pp. 42-52.

Holder, Harold and James Blose. 1985. "Impact of Changes in Distilled Spirits Availability on Alcohol Distribution." Alcohol, Vol. 2, No. 3, pp. 541-544.

Hough, Mike and Gillian Hunter. 2008. "The 2003 Licensing Act's Impact on Crime and Disorder: An Evaluation." Criminology and Criminal Justice, Vol. 8, No. 3, pp. 239-260.

Jofre-Bonet, Mireia and Nancy Petry. 2008. "Trading Apples for Oranges? Results of an Experiment on the Effects of Heroin and Cocaine Price Changes on Addicts' Polydrug Use." Journal of Economic Behavior and Organization, Vol. 66, No. 2, pp. 281-311.

Joksch, Hans and Ralph Jones. 1993. "Changes in the Drinking Age and Crime." Journal of Criminal Justice, Vol. 21, No. 3, pp. 209-221.

Kansas Department of Revenue. 2013. 2013 Kansas Map of Dry Cities (No Retail Sales) Map \#AC13-001. Available at: http://www.ksrevenue.org/pdf/abcNoRetailSales.pdf.

Kansas Legislative Research Department. 2003. Kansas Liquor Laws. Topeka, Kansas: KLRD Publications. Available at: http://skyways.lib.ks.us/ksleg/KLRD/klrd.html.

Kuo, Meichun, Henry Wechsler, Patty Greenberg, and Hang Lee. 2003. "The Marketing of Alcohol to College Students: The Role of Low Prices and Special Promotions." American Journal of Preventative Medicine, Vol. 25, No. 3, pp. 204-211.

Lawless, Michael. 1991. "Commodity Bundling for Competitive Advantage: Strategic Implications.” Journal of Management Studies, Vol. 28, No. 3, pp. 267-280.

Lee, Juliet, Tamar Antin, and Roland Moore. 2008. "Social Organization in Bars: Implications for Tobacco Control Policy.” Contemporary Drug Problems, Vol. 35, pp. 59-98.

Liang, Wenbin and Tanya Chikritzhs. 2011. "Revealing the Link between Licensed Outlets and Violence: Counting Venues Versus Measuring Alcohol Availability." Drug and Alcohol Review, Vol. 30, No. 5, pp. 524-535.

Lipsey, Mark, David Wilson, Mark Cohen, and James Derzon. 1997. "Is there a Causal Relationship between Alcohol Use and Violence?" In Marc Galanter, ed., Recent Developments in Alcoholism, Volume 13: Alcoholism and Violence. New York, NY: Plenum Press. 
Livingston, Michael. 2008a. "Alcohol Outlet Density and Assault: A Spatial Analysis." Addiction, Vol. 103, No. 4, pp. 619-628.

Livingston, Michael. 2008b. “A Longitudinal Analysis of Alcohol Outlet Density and Assault." Alcoholism: Clinical and Experimental Research, Vol. 32, No. 6, pp. 10741079.

Livingston, Michael. 2011. "Alcohol Outlet Density and Harm: Comparing the Impacts on Violence and Chronic Harms.” Drug and Alcohol Review, Vol. 30, No. 5, pp. 515-523.

Lott, Jr., John and John Whitley. 2003. "Measurement Error in County-Level UCR Data." Journal of Quantitative Criminology, Vol. 19, No. 2, pp. 185-198.

Markowitz, Sara. 2000. "The Price of Alcohol, Wife Abuse, and Husband Abuse." Southern Economic Journal, Vol. 67, No. 2, pp. 279-303.

Markowitz, Sara. 2001. "Criminal Violence and Alcohol Beverage Control: Evidence from an International Study." In Michael Grossman and Chee-Ruey Hsieh, eds., The Economics of Substance Use and Abuse: The Experience of Developed Countries and Lessons for Developing Countries. United Kingdom: Edward Elgar Publishing.

Markowitz, Sara. 2005. "Alcohol, Drugs and Violent Crime." International Review of Law and Economics, Vol. 25, No. 1, pp. 20-44.

Markowitz, Sara and Michael Grossman. 2000. "The Effects of Beer Taxes on Physical Child Abuse." Journal of Health Economics, Vol. 19, No. 2, pp. 271-282.

McKinney, Roger. 2009. "Restaurant Owner Pursuing Change in County Liquor Law." The Joplin Globe, March 15. Available at: http://www.joplinglobe.com/x212188933/-img-src-http-www-joplinglobeonline-comimages-zope-extra-gif-border-0-Restaurant-owner-pursuing-change-in-county-liquorlaw-font-color-ff0000-w-Kansas-liquor-law-font/print.

Middleton, Jennifer, Robert Hahn, Jennifer Kuzara, Randy Elder, Robert Brewer, Sajal Chattopadhyay, Jonathan Fielding, Timothy Naimi, Traci Toomey, and Briana Lawrence. 2010. "Effectiveness of Policies Maintaining or Restricting Days of Alcohol Sales on Excessive Alcohol Consumption and Related Harms." American Journal of Preventative Medicine, Vol. 39, No. 6, pp. 575-589.

Miron, Jeffrey. 1999. "Violence and the U.S. Prohibitions on Drugs and Alcohol." American Law and Economics Review, Vol. 1, No. 1, pp. 78-114.

Morris, Robert, Michael TenEyck, J.C. Barnes, and Tomislav Kovandzic. 2014. "The Effect of Medical Marijuana Laws on Crime: Evidence from State Panel Data, 1990-2006." PLOS ONE, Vol. 9, No. 3, e92816. 
O’Connor, Tim. 1987. “Kansas Saloon Doors Open.” The Chicago Tribune, July 1. Available at:

.http://articles.chicagotribune.com/1987-07-01/features/8702180079_1_private-clubswine-and-liquor-alcohol.

Owens, Emily. 2011. "Are Underground Markets Really More Violent? Evidence from Early $20^{\text {th }}$ Century America." American Law and Economics Review, Vol. 13, No. 1, pp. $1-44$.

Petry, Nancy. 2001. "A Behavioral Economic Analysis of Polydrug Abuse in Alcohol Abusers: Asymmetrical Substitution of Alcohol and Cocaine." Drug and Alcohol Dependence, Vol. 62, No. 1, pp. 31-39.

Reid, Robert, Joseph Hughey, and Andrew Peterson. 2003. "Generalizing the Alcohol Outlet Assaultive Violence Link: Evidence from a U.S. Midwestern City." Substance Use and Misuse, Vol. 38, No. 14, pp. 1971-1982.

Reynolds, Kate and Lloyd C. Harris. 2006. "Deviant Customer Behavior: An Exploration of Frontline Employee Tactics." Journal of Marketing Theory and Practice, Vol. 14, No. 2, pp. 95-111.

Robbins, William. 1986. "Kansas Takes on New Image: Days at the Races, and More." The New York Times, November 10. Available at: http://www.nytimes.com/1986/11/10/us/kansas-takes-on-new-image-days-at-the-racesand-more.html.

Robbins, William. 1987. "Kansas Take Drink They Believe Signals an Economic Boom.” The New York Times, July 2. Available at: http://www.nytimes.com/1987/07/02/us/kansans-take-drink-they-believe-signals-aneconomic-boom.html.

Roberts, James. 2007. "Barroom Aggression in Hoboken, New Jersey: Don't Blame the Bouncers!" Journal of Drug Education, Vol. 37, No. 4, pp. 429-445.

Scherer, Ray. 2012. "Doniphan County Passes Liquor by the Drink." St. Joseph News-Press, November 6. Available at: http://www.newspressnow.com/news/local_news/article_5abbb03c-8f15-5c4f-8bb66643a8c14ad6.html.

Scribner, Richard, Deborah Cohen, Stephen Kaplan, and Susan H. Allen. 1999. "Alcohol Availability and Homicide in New Orleans: Conceptual Considerations for Small Area Analysis of the Effect of Alcohol Outlet Density." Journal of Studies on Alcohol, Vol. 60, No. 3, pp. 310-316.

Scribner, Richard, David MacKinnon, and James Dwyer. 1995. "The Risk of Assaultive 
Violence and Alcohol Availability in Los Angeles County." American Journal of Public Health, Vol. 85, No. 3, pp. 335- 340.

Staiger, Douglas and James Stock. 1997. "Instrumental Variables Regression with Weak Instruments." Econometrica, Vol. 65, No. 3, pp. 557-586.

Stites, Tom. 1985. "Businesses Thirst For A 'Wet' Kansas.” Chicago Tribune, March 31. Available at: http://articles.chicagotribune.com/1985-03-31/news/8501180074_1_johncarlin-private-clubs-liquor.

St. John, Sarah. 2012a. "40 Years Ago: Kansas AG Raids Amtrak Train, Confiscates Liquor." Lawrence Journal-World, July 19. Available at: http://www2.ljworld.com/news/2012/jul/19/40-years-ago-kansas-ag-raids-amtrak-trainconfiscal.

St. John, Sarah. 2012b. "25 Years Ago: Tavern Owners Report no Big Changes Today with 'Liquor-by-the-Drink'." Lawrence Journal-World, July 19. Available at: http://www2.ljworld.com/news/2012/jul/01/25-years-ago-tavern-owners-report-no-bigchanges-t/.

Sumnall, Harry, Elizabeth Tyler, Graham Wagstaff, and Jon Cole. 2004. "A Behavioural Economic Analysis of Alcohol, Amphetamine, Cocaine and Ecstasy Purchases by Polysubstance Misusers." Drug and Alcohol Dependence, Vol. 76, No. 1, pp. 93-99.

Teh, Bing-Ru. 2007. "Do Liquor Stores Increase Crime and Urban Decay? Evidence from Los Angeles.” Working Paper, Department of Economics, University of California, Berkeley.

Tomsen, Stephen. 1997. "A Top Night: Social Protest, Masculinity and the Culture of Drinking Violence British Journal of Criminology, Vol. 37 No. 1, pp. 90-102.

Toomey, Traci, Darin Erickson, Bradley Carlin, Kathleen Lenk, Harrison Quick, Alexis Jones, and Eileen Harwood. 2012. "The Association between Density of Alcohol Establishments and Violent Crime within Urban Neighborhoods." Alcoholism: Clinical \& Experimental Research, Vol. 36, No. 8, pp. 1468-1473.

Toplikar, Dave. 1992. "Clubs Start Applying for Change in Licenses." Lawrence Journal-World, November 29. Available at: http://www2.ljworld.com/news/1992/nov/29/clubs_start_applying_for/.

United Press International. 1973. "Two Airlines Agree they Won't Serve Booze in, over Kansas.” Salina Journal, February 20, page 7.

Wheeler, Brian. 2012. "The Slow Death of Prohibition." BBC News, March 21. Available at: http://www.bbc.com/news/magazine-17291978\#TWEET109944.

White, Garland, Randy Gainey, and Ruth Triplett. Forthcoming. "Alcohol Outlets and 
Neighborhood Crime: A Longitudinal Analysis." Crime and Delinquency.

Winn, Russell and David Giacopassi. 1993. "Effects of County-Level Alcohol Prohibition on Motor Vehicle Accidents.” Social Science Quarterly, Vol. 74, No. 4, pp. 783-792.

Wooldridge, Jeffrey. 2013. Introductory Econometrics: A Modern Approach ( $5^{\text {th }}$ edition). Mason, OH: South Western, Cengage Learning.

Zhu, Li, Dennis Gorman, and Scott Horel. 2004. "Alcohol Outlet Density and Violence: A Geospatial Analysis." Alcohol and Alcoholism, Vol. 39, No. 4, pp. 369-375. 


\section{Figure 1. Trends in On-Premises Alcohol Licenses}

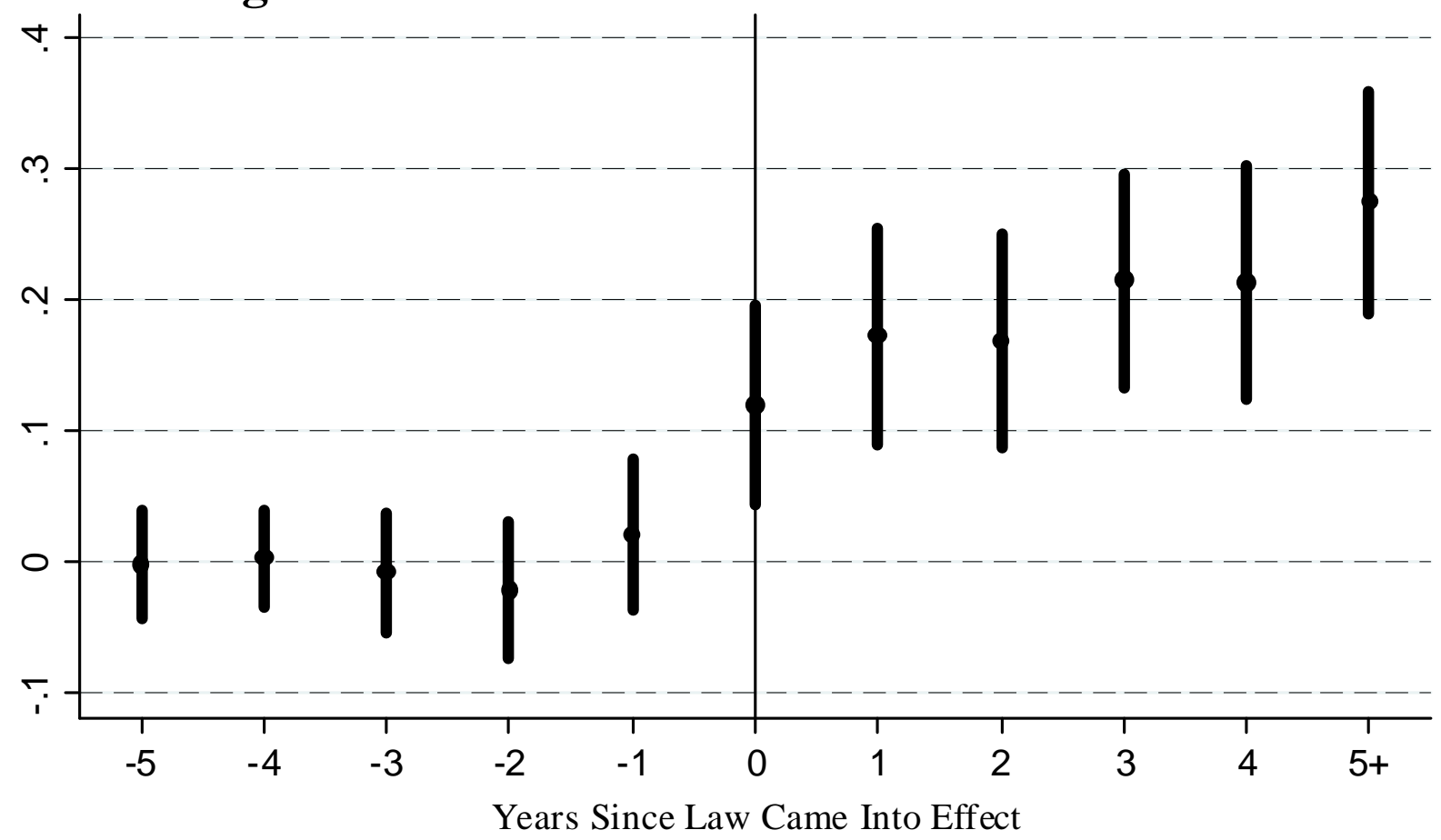

Notes: OLS coefficient estimates (and their 95\% confidence intervals) are reported. The dependent variable is equal to the number of on-premises liquor licenses per 1,000 population in county $c$ and year $t$. The controls include county and year fixed effects and the data cover the period 1977-2011. 
Figure 2. Trends in Off-Premises Alcohol Licenses

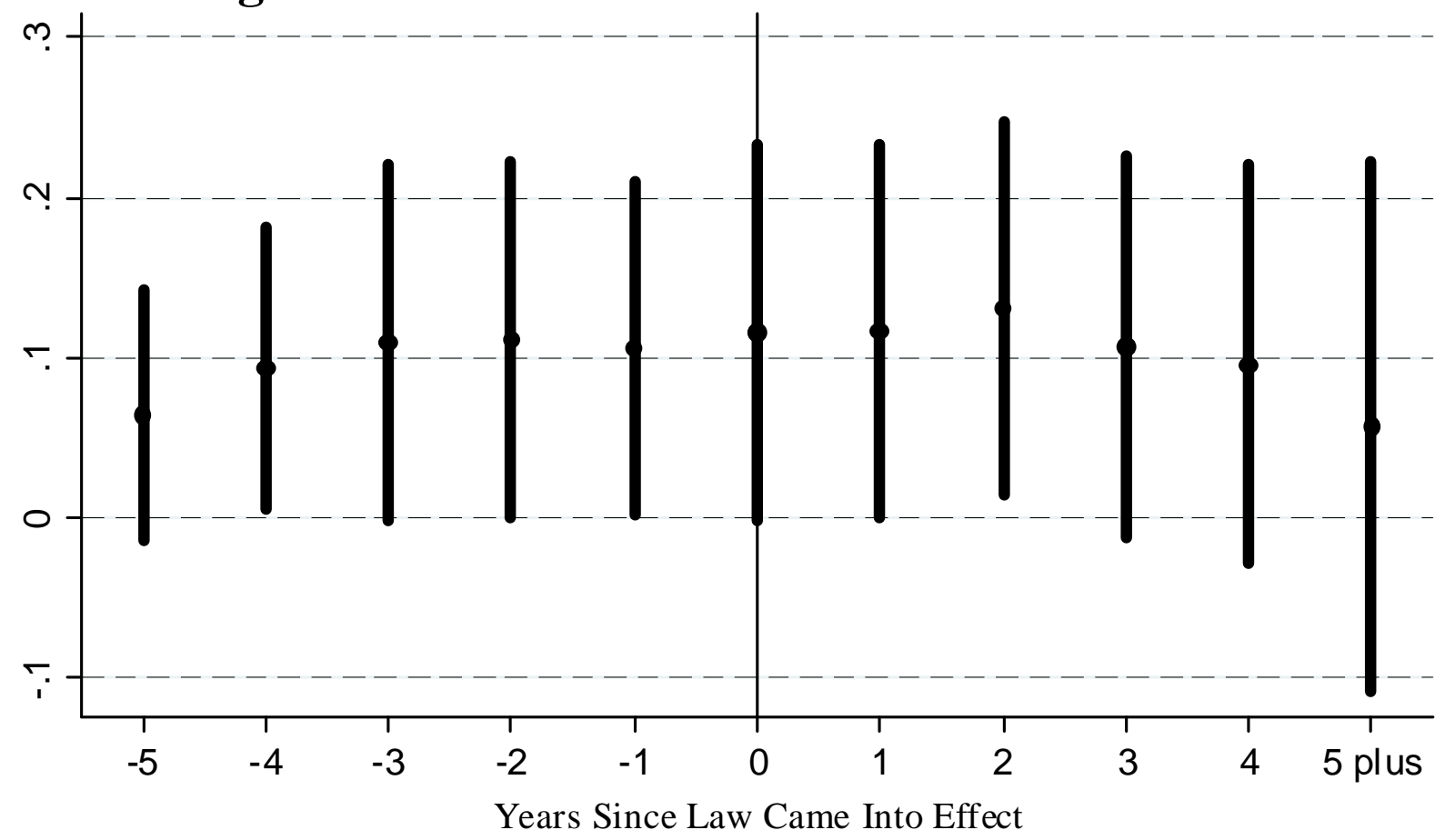

Notes: OLS coefficient estimates (and their $95 \%$ confidence intervals) are reported. The dependent variable is equal to the number of on-premises liquor licenses per 1,000 population in county $c$ and year $t$. The controls include county and year fixed effects and the data cover the period 1977-2011. 
Table 1. Kansas Wet Laws, 1977-2011

\begin{tabular}{|c|c|c|c|c|c|c|c|c|}
\hline & \multicolumn{2}{|c|}{ Year Law Went Into Effect } & \multicolumn{3}{|c|}{ Year Law Went Into Effect } & & \multicolumn{2}{|c|}{ Year Law Went Into Effect } \\
\hline & & Food & & & Food & & & Food \\
\hline & Food Sales & Sales Not & & Food Sales & Sales Not & & Food Sales & Sales Not \\
\hline & $30 \%$ Gross & Required & & $30 \%$ Gross & Required & & $30 \%$ Gross & Required \\
\hline Allen & 2000 & & Greeley & & 2008 & Osborne & 2010 & \\
\hline Anderson & 1996 & & Greenwood & 1986 & & Ottawa & 2006 & \\
\hline Atchison & 1986 & & Hamilton & 2010 & & Pawnee & 1992 & \\
\hline Barber & & 2010 & Harper & 1996 & & Phillips & 1996 & \\
\hline Barton & 1986 & 2004 & Harvey & 1996 & & Pottawatomie & 1986 & \\
\hline Bourbon & 1992 & & Haskell* & & & Pratt & 2000 & \\
\hline Brown & & 2000 & Hodgeman & 2004 & & Rawlins & 2002 & \\
\hline Butler & 1986 & & Jackson & 2004 & & Reno & 1986 & \\
\hline Chase & 1988 & & Jefferson & 1986 & & Republic & 1986 & \\
\hline Chautauqua & 2008 & & Jewell* & & & Rice* & & \\
\hline Cherokee* & & & Johnson & 1986 & & Riley & 1986 & 2004 \\
\hline Cheyenne & 2000 & & Kearny & 1988 & & Rooks & 2000 & \\
\hline Clark* & & & Kingman & 2004 & & Rush & 1986 & \\
\hline Clay* & & & Kiowa & 2010 & & Russell & 1986 & \\
\hline Cloud & 1998 & & Labette & 1996 & & Saline & 1986 & 1994 \\
\hline Coffey & 2004 & & Lane* & & & Scott & & 2010 \\
\hline Comanche & & 2010 & Leavenworth & 1986 & 2010 & Sedgwick & 1986 & 1988 \\
\hline Cowley & & 1996 & Lincoln & 1990 & & Seward & 1996 & \\
\hline Crawford & 1986 & 1992 & Linn & 2004 & & Shawnee & 1986 & 1994 \\
\hline Decatur & 2002 & & Logan & & 2006 & Sheridan* & & \\
\hline Dickinson & 1986 & & Lyon & 1986 & 1992 & Sherman & 1986 & \\
\hline Doniphan* & & & McPherson & 1996 & & Smith & 1992 & \\
\hline Douglas & 1986 & 1992 & Marion & 2004 & & Stafford* & & \\
\hline Edwards & 1986 & 2008 & Marshall & 1986 & & Stanton* & & \\
\hline Elk* & & & Meade* & & & Stevens* & & \\
\hline Ellis & 1986 & 1988 & Miami & 1986 & & Sumner & 1992 & \\
\hline Ellsworth & 1986 & & Mitchell & 1996 & & Thomas & 1986 & \\
\hline Finney & 1986 & & Montgomery & & 1998 & Trego & 1986 & \\
\hline Ford & 1986 & & Morris & 1992 & & Wabaunsee & 1986 & \\
\hline Franklin & 1994 & & Morton* & & & Wallace* & & \\
\hline Geary & 1986 & 1990 & Nemaha & 1986 & & Washington & 1986 & \\
\hline Gove* & & & Neosho & 1998 & & Wichita* & & \\
\hline Graham & & 1992 & Ness & 2004 & & Wilson & 1998 & \\
\hline Grant & & 2008 & Norton & 1992 & & Woodson & & 2008 \\
\hline Gray* & & & Osage & 1986 & & Wyandotte & 1986 & 1988 \\
\hline
\end{tabular}

Notes: Based on information provided by the Kansas Division of Alcoholic Beverage Control. In 1986, voters approved a measure allowing counties to go from "dry" to "wet." This measure garnered a majority of votes in 36 counties and, as of July 1, 1987, establishments in these counties were allowed to sell liquor by the drink. We code these laws as equal to .5 in 1987 and equal to one for the years thereafter.

Subsequent votes to allow by-the-drink sales or remove the food sales requirement took place in November and were officially implemented within a few days. Because the process of obtaining a new liquor license took at least one month, we code these laws as coming into effect on January $1^{\text {st }}$ of the following year. As of 2011, 19 counties in Kansas prohibited on-premises alcohol consumption. These counties are denoted with an asterisk. Sixty-two counties allowed establishments to sell alcohol for on-premises consumption provided that at least 30 percent of gross receipts were from food sales. The remaining 24 Kansas countries allowed on-premises alcohol consumption without requiring food sales. 
Table 2. Descriptive Statistics

\begin{tabular}{|c|c|c|c|c|}
\hline & $\begin{array}{l}\text { Full sample } \\
\text { Mean } \\
\text { (SD) }\end{array}$ & $\begin{array}{l}\text { Wet } \text { Law }=1 \\
\text { Mean } \\
\text { (SD) }\end{array}$ & $\begin{array}{l}\text { Wet Law }=0 \\
\text { Mean } \\
\text { (SD) }\end{array}$ & Description \\
\hline Violent Crime & $\begin{array}{c}3.81 \\
(2.97)\end{array}$ & $\begin{array}{c}4.28 \\
(2.94)\end{array}$ & $\begin{array}{c}3.05 \\
(2.86)\end{array}$ & $\begin{array}{l}\text { Violent crimes in county } c \text { and year } t \text { per } \\
1,000 \text { population }\end{array}$ \\
\hline Property Crime & $\begin{array}{l}40.8 \\
(21.6)\end{array}$ & $\begin{array}{l}42.0 \\
(20.6)\end{array}$ & $\begin{array}{l}38.8 \\
(23.0)\end{array}$ & $\begin{array}{l}\text { Property crimes in county } c \text { and year } t \text { per } \\
1,000 \text { population }\end{array}$ \\
\hline On-Premises Licenses & $\begin{array}{l}.617 \\
(.334)\end{array}$ & $\begin{array}{l}.813 \\
(.223)\end{array}$ & $\begin{array}{l}.295 \\
(.216)\end{array}$ & $\begin{array}{l}\text { Active on-premises alcohol licenses per } \\
1,000 \text { population in county } c \text { and year } t\end{array}$ \\
\hline Income & $\begin{array}{c}26.0 \\
(7.02)\end{array}$ & $\begin{array}{l}28.5 \\
(7.21)\end{array}$ & $\begin{array}{c}21.9 \\
(4.24)\end{array}$ & Real income per capita $(\$ 1,000)$ \\
\hline Unemployment & $\begin{array}{c}4.92 \\
(1.79)\end{array}$ & $\begin{array}{l}5.05 \\
(1.74)\end{array}$ & $\begin{array}{c}4.70 \\
(1.85)\end{array}$ & County unemployment rate \\
\hline Democratic to GOP & $\begin{array}{l}.919 \\
(.579)\end{array}$ & $\begin{array}{l}.954 \\
(.632)\end{array}$ & $\begin{array}{l}.862 \\
(.474)\end{array}$ & $\begin{array}{l}\text { Ratio of Democratic to GOP votes in } \\
\text { presidential and gubernatorial elections }\end{array}$ \\
\hline Population Density & $\begin{array}{c}322.2 \\
(368.8)\end{array}$ & $\begin{array}{c}397.7 \\
(390.1)\end{array}$ & $\begin{array}{l}198.7 \\
(291.9)\end{array}$ & Population per square mile \\
\hline Percent Nonwhite & $\begin{array}{l}.087 \\
(.076)\end{array}$ & $\begin{array}{l}.103 \\
(.077)\end{array}$ & $\begin{array}{l}.060 \\
(.065)\end{array}$ & $\begin{array}{l}\text { Percent of the county population that was } \\
\text { nonwhite }\end{array}$ \\
\hline Percent Adult Male & $\begin{array}{l}.356 \\
(.021)\end{array}$ & $\begin{array}{l}.360 \\
(.021)\end{array}$ & $\begin{array}{l}.350 \\
(.021)\end{array}$ & $\begin{array}{l}\text { Percent of the county population that was } \\
\text { male and } 18+\text { years of age }\end{array}$ \\
\hline Percent 21 and Over & $\begin{array}{l}.687 \\
(.026)\end{array}$ & $\begin{array}{l}.692 \\
(.023)\end{array}$ & $\begin{array}{l}.678 \\
(.029)\end{array}$ & $\begin{array}{l}\text { Percent of the county population that was } \\
21+\text { years of age }\end{array}$ \\
\hline Sunday Sales & $\begin{array}{l}.189 \\
(.391)\end{array}$ & $\begin{array}{l}.299 \\
(.458)\end{array}$ & $\begin{array}{l}.009 \\
(.094)\end{array}$ & $\begin{array}{l}=1 \text { if Sunday sales of alcohol for off- } \\
\text { premises consumption were legal anywhere } \\
\text { within the county, = } 0 \text { otherwise }\end{array}$ \\
\hline $\mathrm{N}$ & 3,352 & 1,291 & 2,061 & \\
\hline
\end{tabular}

Note: Crime data come from the Uniform Crime Reports and the Kansas Statistical Abstract. Data on income per capita, the unemployment rate, and the Democratic to GOP voting ratio come from the Institute for Policy and Social Research at the University of Kansas (http://ipsr.ku.edu/ksdata/). Population data come from the U.S. Census. The Kansas Department of Revenue provided the authors with a list of municipalities that currently allow Sunday sales of alcohol for off-premises consumption. Effective dates for Sunday sales were acquired by searching municipal codes, local newspapers, and town council minutes, or contacting municipal clerks directly. The years 1995, 1996, and 1999 are excluded because of missing crime data. Means are weighted by county population and standard deviations are shown in parentheses. 
Table 3. First-Stage: Wet Laws and On-Premises Alcohol Licenses, 1977-2011

\begin{tabular}{lcc}
\hline & On-Premises Licenses & On-Premises Licenses \\
\hline Wet Law & $.177^{* * *}$ & $.143^{* * *}$ \\
& $(.025)$ & $(.022)$ \\
$\mathrm{N}$ & 3,352 & 3,352 \\
$\mathrm{R}^{2}$ & .893 & .942 \\
& & \\
Year FEs & Yes & Yes \\
County FEs & Yes & Yes \\
Covariates & Yes & Yes \\
County linear trends & No & Yes \\
\hline
\end{tabular}

*Statistically significant at $10 \%$ level; ** at $5 \%$ level; *** at $1 \%$ level.

Notes: Each column represents the results from a separate OLS regression. The dependent variable is equal to the number of active on-premises alcohol licenses per 1,000 population in county $c$ and year $t$. The years 1995, 1996, and 1999 are excluded because of missing crime data. A list of covariates is provided in Table 2 . Regressions are weighted by county population and standard errors are corrected for clustering at the county level. 
Table 4. On-Premises Licenses and Violent Crime, 1977-2011

\begin{tabular}{lcccc}
\hline & OLS & OLS & 2SLS & 2SLS \\
& Violent Crime & Violent Crime & Violent Crime & Violent Crime \\
\hline On-Premises Licenses & $.853^{*}$ & $1.24^{*}$ & $4.31^{* *}$ & $5.00^{* * *}$ \\
& $(.500)$ & $(.667)$ & $(1.77)$ & $(1.87)$ \\
$\mathrm{N}$ & 3,352 & 3,352 & 3,352 & 3,352 \\
$\mathrm{R}^{2}$ & .758 & .847 & .740 & .836 \\
& & & & \\
F-test of instrument & $\ldots$ & $\ldots$ & 51.9 & 41.9 \\
& & & & \\
Year FEs & Yes & Yes & Yes & Yes \\
County FEs & Yes & Yes & Yes & Yes \\
Covariates & Yes & Yes & Yes & Yes \\
County linear trends & No & Yes & No & Yes \\
\hline
\end{tabular}

*Statistically significant at $10 \%$ level; ** at $5 \%$ level; *** at $1 \%$ level.

Notes: Each column represents the results from a separate OLS regression. The dependent variable is equal to the number of violent crimes per 1,000 population in county $c$ and year $t$. The years 1995, 1996, and 1999 are excluded because of missing crime data. A list of covariates is provided in Table 2. Regressions are weighted by county population and standard errors are corrected for clustering at the county level. 
Table 5. On-Premises Licenses and Violent Crime by Crime Type, 1977-2011

\begin{tabular}{|c|c|c|c|c|c|c|c|c|c|c|}
\hline & $\begin{array}{l}\text { Violent } \\
\text { Crime }\end{array}$ & $\begin{array}{l}\text { Violent } \\
\text { Crime }\end{array}$ & Murder & Murder & Rape & Rape & Robbery & Robbery & Assault & Assault \\
\hline On-Premises Licenses & $\begin{array}{l}4.36 * * \\
(1.92)\end{array}$ & $\begin{array}{l}5.38 * * \\
(2.19)\end{array}$ & $\begin{array}{c}.017 \\
(.032)\end{array}$ & $\begin{array}{c}.044 \\
(.049)\end{array}$ & $\begin{array}{l}.361 * * \\
(.157)\end{array}$ & $\begin{array}{l}.421 * * \\
(.170)\end{array}$ & $\begin{array}{c}1.46^{*} \\
(.777)\end{array}$ & $\begin{array}{c}2.53 * * \\
(1.12)\end{array}$ & $\begin{array}{c}2.52 * * \\
(1.28)\end{array}$ & $\begin{array}{c}2.39 \\
(1.63)\end{array}$ \\
\hline $\mathrm{N}$ & 2,932 & 2,932 & 2,932 & 2,932 & 2,932 & 2,932 & 2,932 & 2,932 & 2,932 & 2,932 \\
\hline $\mathrm{R}^{2}$ & .729 & .833 & .505 & .528 & .667 & .744 & .803 & .838 & .612 & .790 \\
\hline F-test of instrument & 54.2 & 42.6 & 54.2 & 42.6 & 54.2 & 42.6 & 54.2 & 42.6 & 54.2 & 42.6 \\
\hline Year FEs & Yes & Yes & Yes & Yes & Yes & Yes & Yes & Yes & Yes & Yes \\
\hline County FEs & Yes & Yes & Yes & Yes & Yes & Yes & Yes & Yes & Yes & Yes \\
\hline Covariates & Yes & Yes & Yes & Yes & Yes & Yes & Yes & Yes & Yes & Yes \\
\hline County linear trends & No & Yes & No & Yes & No & Yes & No & Yes & No & Yes \\
\hline
\end{tabular}

*Statistically significant at $10 \%$ level; ** at 5\% level; *** at $1 \%$ level.

Notes: Each column represents the results from a separate 2SLS regression. Crime in county $c$ and year $t$ is measured per 1,000 population. The years $1993-$

1999 are excluded because of missing crime data. A list of covariates is provided in Table 2 and means of violent crimes by type are provided in Appendix

Table 2. Regressions are weighted by county population and standard errors are corrected for clustering at the county level. 
Table 6. Reduced-form Relationship between Wet Laws and Violent Crime, 1977-2011

\begin{tabular}{|c|c|c|c|c|c|c|c|}
\hline & $\begin{array}{l}\text { Violent } \\
\text { Crime }\end{array}$ & $\begin{array}{l}\text { Violent } \\
\text { Crime }\end{array}$ & $\begin{array}{l}\text { Violent } \\
\text { Crime }\end{array}$ & $\begin{array}{l}\text { Violent } \\
\text { Crime }\end{array}$ & $\begin{array}{l}\text { Violent } \\
\text { Crime }\end{array}$ & $\begin{array}{l}\text { Violent } \\
\text { Crime }\end{array}$ & $\begin{array}{l}\text { Violent } \\
\text { Crime }\end{array}$ \\
\hline Wet Law & $\begin{array}{l}.761 * * \\
(.306)\end{array}$ & $\begin{array}{l}.714 * * \\
(.281)\end{array}$ & $\ldots$ & $\ldots$ & $\ldots$ & $\ldots$ & $\ldots$ \\
\hline 7 Years before Wet Law & $\ldots$ & $\ldots$ & $\cdots$ & $\cdots$ & $\cdots$ & $\ldots$ & $\begin{array}{l}.309 * \\
(.161)\end{array}$ \\
\hline 6 Years before Wet Law & $\ldots$ & $\cdots$ & .. & $\ldots$ & $\ldots$ & $\begin{array}{l}.196 \\
(.147)\end{array}$ & $\begin{array}{l}.264 \\
(.175)\end{array}$ \\
\hline 5 Years before Wet Law & .. & $\ldots$ & $\ldots$ & $\ldots$ & $\begin{array}{l}-.261 \\
(.169)\end{array}$ & $\begin{array}{l}-.226 \\
(.183)\end{array}$ & $\begin{array}{l}-.146 \\
(.206)\end{array}$ \\
\hline 4 Years before Wet Law & $\ldots$ & .. & $\ldots$ & $\begin{array}{l}-.314^{*} \\
(.166)\end{array}$ & $\begin{array}{c}-.362 * * \\
(.177)\end{array}$ & $\begin{array}{l}-.322 * \\
(.192)\end{array}$ & $\begin{array}{l}-.248 \\
(.212)\end{array}$ \\
\hline 3 Years before Wet Law & $\ldots$ & .. & $\ldots$ & $\begin{array}{l}-.018 \\
(.219)\end{array}$ & $\begin{array}{l}-.072 \\
(.223)\end{array}$ & $\begin{array}{l}-.035 \\
(.237)\end{array}$ & $\begin{array}{l}.049 \\
(.264)\end{array}$ \\
\hline 2 Years before Wet Law & $\ldots$ & $\cdots$ & .. & $\begin{array}{l}.203 \\
(.258)\end{array}$ & $\begin{array}{l}.154 \\
(.261)\end{array}$ & $\begin{array}{l}.196 \\
(.280)\end{array}$ & $\begin{array}{c}.273 \\
(.309)\end{array}$ \\
\hline 1 Year before Wet Law & $\ldots$ & .. & $\ldots$ & $\begin{array}{c}.481 \\
(.341)\end{array}$ & $\begin{array}{c}.424 \\
(.342)\end{array}$ & $\begin{array}{c}.463 \\
(.359)\end{array}$ & $\begin{array}{l}.566 \\
(.397)\end{array}$ \\
\hline Year of Law Change & .. & .. & $\begin{array}{l}.199 \\
(.250)\end{array}$ & $\begin{array}{c}.238 \\
(.341)\end{array}$ & $\begin{array}{l}.184 \\
(.339)\end{array}$ & $\begin{array}{l}.237 \\
(.361)\end{array}$ & $\begin{array}{c}.324 \\
(.389)\end{array}$ \\
\hline 1 Year after Wet Law & ... & .. & $\begin{array}{c}.412 \\
(.270)\end{array}$ & $\begin{array}{c}.462 \\
(.361)\end{array}$ & $\begin{array}{c}.389 \\
(.361)\end{array}$ & $\begin{array}{c}.432 \\
(.380)\end{array}$ & $\begin{array}{l}.531 \\
(.417)\end{array}$ \\
\hline 2 Years after Wet Law & $\cdots$ & $\ldots$ & $\begin{array}{l}.794 * * \\
(.319)\end{array}$ & $\begin{array}{l}.819 * * \\
(.404)\end{array}$ & $\begin{array}{l}.762 * \\
(.405)\end{array}$ & $\begin{array}{l}.810^{*} \\
(.426)\end{array}$ & $\begin{array}{l}.899 * \\
(.462)\end{array}$ \\
\hline 3 Years after Wet Law & .. & $\ldots$ & $\begin{array}{l}1.05 * * \\
(.455)\end{array}$ & $\begin{array}{l}1.10 * * \\
(.554)\end{array}$ & $\begin{array}{l}1.03^{*} \\
(.548)\end{array}$ & $\begin{array}{l}1.08 * \\
(.565)\end{array}$ & $\begin{array}{l}1.22 * \\
(.620)\end{array}$ \\
\hline 4 Years after Wet Law & $\ldots$ & $\ldots$ & $\begin{array}{c}1.10 * * * \\
(.410)\end{array}$ & $\begin{array}{l}1.15^{* *} \\
(.501)\end{array}$ & $\begin{array}{l}1.09 * * \\
(.493)\end{array}$ & $\begin{array}{l}1.16 * * \\
(.520)\end{array}$ & $\begin{array}{l}1.27 * * \\
(.559)\end{array}$ \\
\hline $5+$ Years after Wet Law & & & $\begin{array}{l}.625^{*} \\
(.326)\end{array}$ & $\begin{array}{l}.699 * \\
(.362)\end{array}$ & $\begin{array}{l}.606^{*} \\
(.341)\end{array}$ & $\begin{array}{l}.670^{*} \\
(.344)\end{array}$ & $\begin{array}{l}.804 * * \\
(.367)\end{array}$ \\
\hline $\begin{array}{l}\mathrm{N} \\
\mathrm{R}^{2}\end{array}$ & $\begin{array}{c}3,352 \\
.759\end{array}$ & $\begin{array}{c}3,352 \\
.847\end{array}$ & $\begin{array}{c}3,352 \\
.848\end{array}$ & $\begin{array}{c}3,352 \\
.848\end{array}$ & $\begin{array}{c}3,352 \\
.848\end{array}$ & $\begin{array}{c}3,352 \\
.848\end{array}$ & $\begin{array}{c}3,352 \\
.849\end{array}$ \\
\hline $\begin{array}{l}\text { Year FEs } \\
\text { County FEs } \\
\text { Covariates } \\
\text { County linear trends }\end{array}$ & $\begin{array}{l}\text { Yes } \\
\text { Yes } \\
\text { Yes } \\
\text { No }\end{array}$ & $\begin{array}{l}\text { Yes } \\
\text { Yes } \\
\text { Yes } \\
\text { Yes }\end{array}$ & $\begin{array}{l}\text { Yes } \\
\text { Yes } \\
\text { Yes } \\
\text { Yes }\end{array}$ & $\begin{array}{l}\text { Yes } \\
\text { Yes } \\
\text { Yes } \\
\text { Yes }\end{array}$ & $\begin{array}{l}\text { Yes } \\
\text { Yes } \\
\text { Yes } \\
\text { Yes }\end{array}$ & $\begin{array}{l}\text { Yes } \\
\text { Yes } \\
\text { Yes } \\
\text { Yes }\end{array}$ & $\begin{array}{l}\text { Yes } \\
\text { Yes } \\
\text { Yes } \\
\text { Yes }\end{array}$ \\
\hline
\end{tabular}

*Statistically significant at $10 \%$ level; ** at $5 \%$ level; *** at $1 \%$ level.

Notes: Each column represents the results from a separate OLS regression. The dependent variable is equal to the number of violent crimes per 1,000 population in county $c$ and year $t$. The years 1995, 1996, and 1999 are excluded because of missing crime data. A list of covariates is provided in Table 2. Regressions are weighted by county population and standard errors are corrected for clustering at the county level. 
Table 7. Reduced-form Relationship between Wet Laws and Violent Crime by Crime Type, 1977-2011

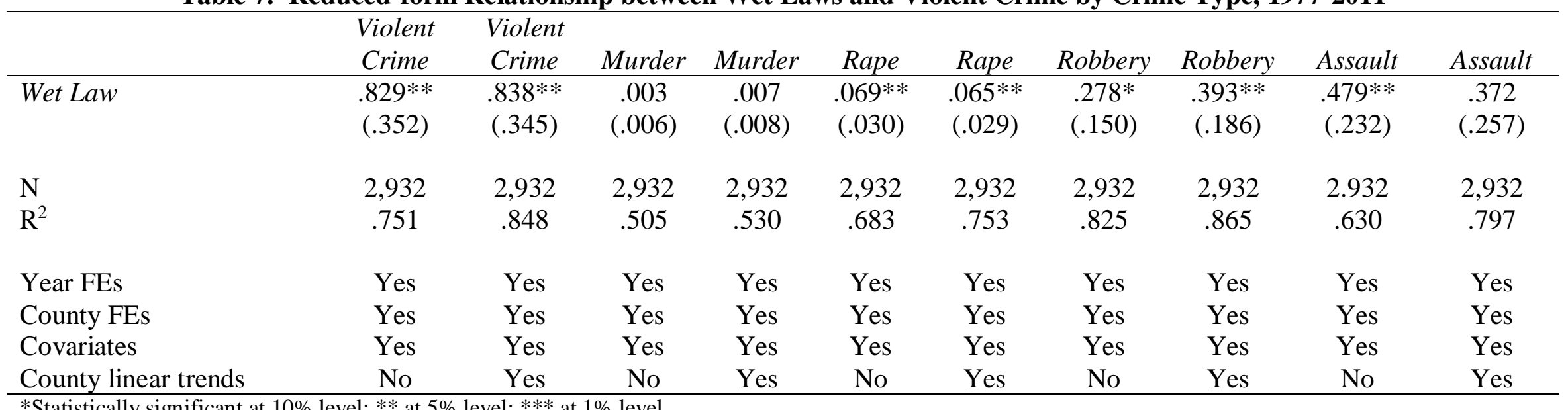

*Statistically significant at $10 \%$ level; $* *$ at $5 \%$ level; *** at $1 \%$ level.

Notes: Each column represents the results from a separate OLS regression. Crime in county $c$ and year $t$ is measured per 1,000 population. The years $1993-1999$ are excluded because of missing crime data. A list of covariates is provided in Table 2 and means of violent crimes by type are provided in Appendix Table 2.

Regressions are weighted by county population and standard errors are corrected for clustering at the county level. 
Table 8. Robustness Checks, Violent Crime

\begin{tabular}{|c|c|c|c|c|c|c|c|}
\hline & $\begin{array}{l}\text { Placebo } \\
\text { Wet Law }\end{array}$ & $\begin{array}{c}\text { Restrict to } \\
\text { counties with } \\
\text { population }> \\
5,000 \\
\end{array}$ & $\begin{array}{c}\text { Restrict to } \\
\text { counties with } \\
\text { population }> \\
10,000 \\
\end{array}$ & $\begin{array}{c}\text { Control for } \\
\text { county-specific } \\
\text { quadratic time } \\
\text { trends }\end{array}$ & $\begin{array}{c}\text { Control for } \\
\text { crack epidemic }\end{array}$ & $\begin{array}{c}\text { Dependent } \\
\text { variable = } \\
\ln (\text { Violent } \\
\text { Crime })\end{array}$ & $\begin{array}{l}\text { Negative } \\
\text { binomial }\end{array}$ \\
\hline & (1) & $(2)$ & $(3)$ & $(4)$ & $(5)$ & (6) & $(7)$ \\
\hline & $\begin{array}{l}\text { Violent } \\
\text { Crime }\end{array}$ & $\begin{array}{l}\text { Violent } \\
\text { Crime }\end{array}$ & $\begin{array}{l}\text { Violent } \\
\text { Crime }\end{array}$ & $\begin{array}{l}\text { Violent } \\
\text { Crime }\end{array}$ & $\begin{array}{l}\text { Violent } \\
\text { Crime }\end{array}$ & $\begin{array}{l}\text { Violent } \\
\text { Crime }\end{array}$ & $\begin{array}{l}\text { Violent } \\
\text { Crime }\end{array}$ \\
\hline Average placebo Wet Law estimate & -.022 & $\ldots$ & $\ldots$ & $\ldots$ & $\ldots$ & $\ldots$ & $\ldots$ \\
\hline Wet Law & $\ldots$ & $\begin{array}{l}.741 * * \\
(.300)\end{array}$ & $\begin{array}{l}.895^{* *} \\
(.387)\end{array}$ & $\begin{array}{l}.926 * * \\
(.449)\end{array}$ & $\begin{array}{l}.769 * * \\
(.327)\end{array}$ & $\begin{array}{l}.102 * * \\
(.048)\end{array}$ & $\begin{array}{l}.117 * \\
(.065)\end{array}$ \\
\hline $\mathrm{N}$ & 3,352 & 2,299 & 1,366 & 3,352 & 3,352 & 3,352 & 3,352 \\
\hline Number of trials & 100 & $\ldots$ & $\ldots$ & $\ldots$ & $\ldots$ & $\cdots$ & $\cdots$ \\
\hline $\begin{array}{l}\text { Placebo coefficient }>0 \text { and significant } \\
\text { at } 5 \% \text { level }\end{array}$ & 2 & $\ldots$ & $\ldots$ & $\cdots$ & $\cdots$ & $\cdots$ & $\cdots$ \\
\hline Year FEs & Yes & Yes & Yes & Yes & Yes & Yes & Yes \\
\hline County FEs & Yes & Yes & Yes & Yes & Yes & Yes & Yes \\
\hline Covariates & Yes & Yes & Yes & Yes & Yes & Yes & Yes \\
\hline County linear trends & Yes & Yes & Yes & Yes & Yes & Yes & Yes \\
\hline
\end{tabular}

*Statistically significant at $10 \%$ level; ** at $5 \%$ level; *** at $1 \%$ level.

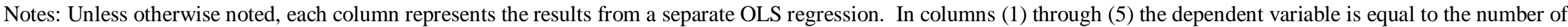

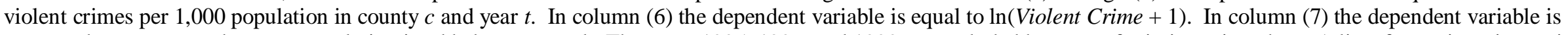

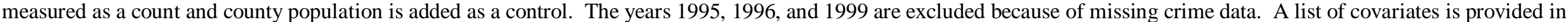
Table 2. Regressions are weighted by county population and standard errors are corrected for clustering at the county level. 
Table 9. Wet Laws and Sworn Officer Employment

\begin{tabular}{lcc}
\hline & $\begin{array}{c}\text { Officers Employed } \\
\text { by Sheriffs' Offices }\end{array}$ & $\begin{array}{c}\text { Officers Employed } \\
\text { by Police Depts. }\end{array}$ \\
\hline Wet Law & -.033 & -.037 \\
Mean of dependent variable & $(.047)$ & $(.045)$ \\
$\mathrm{N}$ & .718 & 1.40 \\
$\mathrm{R}^{2}$ & 1,731 & 1,711 \\
& .866 & .811 \\
Year FEs & & \\
County FEs & Yes & Yes \\
Covariates & Yes & Yes \\
County linear trends & Yes & Yes \\
\hline
\end{tabular}

*Statistically significant at $10 \%$ level; ** at $5 \%$ level; *** at $1 \%$ level.

Notes: Each column represents the results from a separate OLS regression. Law enforcement employment data come from the annual publication Crime in the United States and are available for the period 1995 through 2011. The dependent variable is equal to the number of sworn officers per 1,000 population in county $c$ and year $t$. A list of covariates is provided in Table 2. In the police employment regression, we also controlled for the number of police departments reporting data in a county-year. Regressions are weighted by county population and standard errors are corrected for clustering at the county level. 
Table 10. Economic Conditions, the Democratic to GOP Voting Ratio, and Wet Laws

\begin{tabular}{lcc}
\hline & Wet Law & Wet Law \\
\hline Income & .002 & .007 \\
& $(.005)$ & $(.005)$ \\
Unemployment & -.014 & -.005 \\
& $(.009)$ & $(.009)$ \\
Democratic to GOP & -.029 & \\
& $(.029)$ & -.044 \\
& & $(.035)$ \\
Mean of dependent variable & .629 & \\
& & .629 \\
$\mathrm{~N}$ & 3,675 & 3,675 \\
$\mathrm{R}^{2}$ & .840 & .876 \\
& & \\
Year FEs & Yes & Yes \\
County FEs & Yes & Yes \\
Covariates & Yes & Yes \\
County linear trends & No & Yes \\
\hline *Statistically significant at $10 \%$ level; ** at 5\% level; *** at 1\% level. &
\end{tabular}

Notes: Each column represents the results from a separate OLS regression. The dependent variable is equal to one if county $c$ allowed by-the-drink sales to the general public in year $t$ (and is equal to zero otherwise). A list of covariates is provided in Table 2 . Regressions are weighted by county population and standard errors are corrected for clustering at the county level. 
Table 11. Distinguishing between Wet Laws with and without the 30 Percent Food Sales Requirement

\begin{tabular}{lcc}
\hline Wet Law with Food Sales 30\% Gross & Violent Crime & Violent Crime \\
& $.686^{* *}$ & $.695^{* *}$ \\
& $(.300)$ & $(.281)$ \\
Wet Law with Food Sales Not Required & $1.26^{* *}$ & $.875^{*}$ \\
& $(.607)$ & $(.509)$ \\
$\mathrm{N}$ & & \\
$\mathrm{R}^{2}$ & 3,352 & 3,352 \\
& .760 & .847 \\
Year FEs & & \\
County FEs & Yes & Yes \\
Covariates & Yes & Yes \\
County linear trends & Yes & Yes \\
\hline *Statisticlly significant at $10 \%$ No & Yes \\
\hline
\end{tabular}

*Statistically significant at $10 \%$ level; ** at $5 \%$ level; *** at $1 \%$ level.

Notes: Each column represents the results from a separate OLS regression. The dependent variable is equal to the number of violent crimes per 1,000 population in county $c$ and year $t$. The years 1995, 1996, and 1999 are excluded because of missing crime data. A list of covariates is provided in Table 2 . Regressions are weighted by county population and standard errors are corrected for clustering at the county level. 
Table 12. Did Wet Laws Create or Displace Violent Crime? Adding Bordering Wet Counties to the Model

\begin{tabular}{|c|c|c|c|c|c|c|}
\hline & \multicolumn{2}{|c|}{ Full sample } & \multicolumn{2}{|c|}{ Always-dry counties } & \multirow{2}{*}{$\begin{array}{c}\text { Full sample } \\
\text { (5) } \\
\text { Violent Crime }\end{array}$} & \multirow{2}{*}{$\begin{array}{c}\text { Always-dry counties } \\
(6) \\
\text { Violent Crime }\end{array}$} \\
\hline & $\begin{array}{c}\text { (1) } \\
\text { Violent Crime }\end{array}$ & $\begin{array}{c}(2) \\
\text { Violent Crime }\end{array}$ & $\begin{array}{c}(3) \\
\text { Violent Crime }\end{array}$ & $\begin{array}{c}(4) \\
\text { Violent Crime }\end{array}$ & & \\
\hline Wet Law & $\begin{array}{l}.711 * * \\
(.327)\end{array}$ & $\begin{array}{l}.735^{* *} \\
(.328)\end{array}$ & $\ldots$ & $\ldots$ & $\begin{array}{c}.692 * * \\
(.314)\end{array}$ & $\ldots$ \\
\hline $\begin{array}{l}\text { Number of Wet Counties } \\
\text { on Border }\end{array}$ & $\begin{array}{c}.003 \\
(.143)\end{array}$ & $\ldots$ & $\begin{array}{l}.048 \\
(.118)\end{array}$ & $\ldots$ & $\ldots$ & $\cdots$ \\
\hline $\begin{array}{l}\text { One Wet County on } \\
\text { Border }\end{array}$ & $\ldots$ & $\begin{array}{l}.281 \\
(.629)\end{array}$ & $\cdots$ & $\begin{array}{l}-.075 \\
(.343)\end{array}$ & $\cdots$ & $\ldots$ \\
\hline $\begin{array}{l}\text { Two or More Wet } \\
\text { Counties on Border }\end{array}$ & $\ldots$ & $\begin{array}{l}-.001 \\
(.712)\end{array}$ & $\ldots$ & $\begin{array}{l}.055 \\
(.302)\end{array}$ & $\cdots$ & $\cdots$ \\
\hline $\begin{array}{l}\text { Number of Wet Counties } \\
\text { on Border with Food } \\
\text { Sales Requirement }\end{array}$ & $\ldots$ & $\ldots$ & .. & $\cdots$ & $\begin{array}{l}-.004 \\
(.147)\end{array}$ & $\begin{array}{c}.047 \\
(.108)\end{array}$ \\
\hline $\begin{array}{l}\text { Number of Wet Counties } \\
\text { on Border without Food } \\
\text { Sales Requirement }\end{array}$ & $\cdots$ & $\ldots$ & $\cdots$ & $\ldots$ & $\begin{array}{c}.307 \\
(.326)\end{array}$ & $\begin{array}{c}.055 \\
(.277)\end{array}$ \\
\hline $\begin{array}{l}\mathrm{N} \\
\mathrm{R}^{2}\end{array}$ & $\begin{array}{c}3,352 \\
.847\end{array}$ & $\begin{array}{c}3,352 \\
.847\end{array}$ & $\begin{array}{l}607 \\
.591\end{array}$ & $\begin{array}{l}607 \\
.591\end{array}$ & $\begin{array}{c}3,352 \\
.848\end{array}$ & $\begin{array}{l}607 \\
.591\end{array}$ \\
\hline $\begin{array}{l}\text { Year FEs } \\
\text { County FEs } \\
\text { Covariates } \\
\text { County linear trends }\end{array}$ & $\begin{array}{l}\text { Yes } \\
\text { Yes } \\
\text { Yes } \\
\text { Yes }\end{array}$ & $\begin{array}{l}\text { Yes } \\
\text { Yes } \\
\text { Yes } \\
\text { Yes }\end{array}$ & $\begin{array}{l}\text { Yes } \\
\text { Yes } \\
\text { Yes } \\
\text { Yes }\end{array}$ & $\begin{array}{l}\text { Yes } \\
\text { Yes } \\
\text { Yes } \\
\text { Yes }\end{array}$ & $\begin{array}{l}\text { Yes } \\
\text { Yes } \\
\text { Yes } \\
\text { Yes }\end{array}$ & $\begin{array}{l}\text { Yes } \\
\text { Yes } \\
\text { Yes } \\
\text { Yes }\end{array}$ \\
\hline
\end{tabular}

*Statistically significant at $10 \%$ level; ** at $5 \%$ level; *** at $1 \%$ level.

Notes: Each column represents the results from a separate OLS regression. The dependent variable is equal to the number of violent crimes per 1,000 population in county $c$ and year $t$. The years 1995, 1996, and 1999 are excluded because of missing crime data. A list of covariates is provided in Table 2 . Regressions are weighted by county population and standard errors are corrected for clustering at the county level. 
Table 13. On-Premises Consumption of Alcohol and Property Crime, 1977-2011

\begin{tabular}{lcccc}
\hline & $\begin{array}{c}2 \text { SLS } \\
\text { Property Crime }\end{array}$ & $\begin{array}{c}\text { 2SLS } \\
\text { Property Crime }\end{array}$ & $\begin{array}{c}\text { Reduced-form } \\
\text { Property Crime }\end{array}$ & $\begin{array}{c}\text { Reduced-form } \\
\text { Property Crime }\end{array}$ \\
\hline On-Premises Licenses & 15.2 & $26.6^{* *}$ & $\ldots$ & $\ldots$ \\
Wet Law & $(10.4)$ & $(11.5)$ & $\ldots .68$ & $3.81^{* *}$ \\
& $\ldots$ & $\ldots$ & $(1.93)$ & $(1.83)$ \\
$\mathrm{N}$ & & & & 3,352 \\
$\mathrm{R}^{2}$ & 3,352 & 3,352 & .832 & .872 \\
& .835 & .869 & & $\ldots$ \\
F-test of instrument & 51.9 & 41.9 & $\ldots$ & \\
& & & & \\
Year FEs & Yes & Yes & Yes & Yes \\
County FEs & Yes & Yes & Yes & Yes \\
Covariates & Yes & Yes & Yes & Yes \\
County linear trends & No & Yes & No & Yes \\
\hline
\end{tabular}

*Statistically significant at $10 \%$ level; ** at $5 \%$ level; *** at $1 \%$ level.

Notes: Each column represents the results from a separate regression. The dependent variable is equal to the number of property crimes per 1,000 population in county $c$ and year $t$. The years 1995, 1996, and 1999 are excluded because of missing crime data. A list of covariates is provided in Table 2. Regressions are weighted by county population and standard errors are corrected for clustering at the county level. 
Table 14. Reduced-form Relationship between Wet Laws and Property Crime by Crime Type, 1977-2011

\begin{tabular}{lcccccccc}
\hline & & & & & & & \multicolumn{3}{c}{$\begin{array}{c}\text { Motor } \\
\text { Vehicle }\end{array}$} & $\begin{array}{c}\text { Motor } \\
\text { Vehicle }\end{array}$ \\
& $\begin{array}{c}\text { Property } \\
\text { Crime }\end{array}$ & $\begin{array}{c}\text { Property } \\
\text { Crime }\end{array}$ & Burglary & Burglary & Larceny & Larceny & Theft & Theft \\
\hline Wet Law & 3.15 & $5.13^{* *}$ & .262 & .874 & $2.28^{*}$ & $3.40^{* * * *}$ & $.609^{* *}$ & $.859^{* *}$ \\
& $(2.03)$ & $(2.00)$ & $(.753)$ & $(.759)$ & $(1.19)$ & $(1.14)$ & $(.305)$ & $(.395)$ \\
$\mathrm{N}$ & & & & & & & & \\
$\mathrm{R}^{2}$ & 2,932 & 2,932 & 2,932 & 2,932 & 2,932 & 2,932 & 2,932 & 2,932 \\
& .835 & .869 & .834 & .883 & .827 & .861 & .731 & .752 \\
Year FEs & & & & & & & & \\
County FEs & Yes & Yes & Yes & Yes & Yes & Yes & Yes & Yes \\
Covariates & Yes & Yes & Yes & Yes & Yes & Yes & Yes & Yes \\
County linear trends & Yes & Yes & Yes & Yes & Yes & Yes & Yes & Yes \\
\hline & No & Yes & No & Yes & No & Yes & No & Yes \\
\hline
\end{tabular}

*Statistically significant at $10 \%$ level; ** at $5 \%$ level; *** at $1 \%$ level.

Notes: Each column represents the results from a separate OLS regression. Crime in county $c$ and year $t$ is measured per 1,000 population. The years 1993-1999 are excluded because of missing crime data. A list of covariates is provided in Table 2 and means of property crimes by type are provided in Appendix Table 2. Regressions are weighted by county population and standard errors are corrected for clustering at the county level. 
Table 15. Did Wet Laws Create or Displace Property Crime? Adding Bordering Wet Counties to the Model

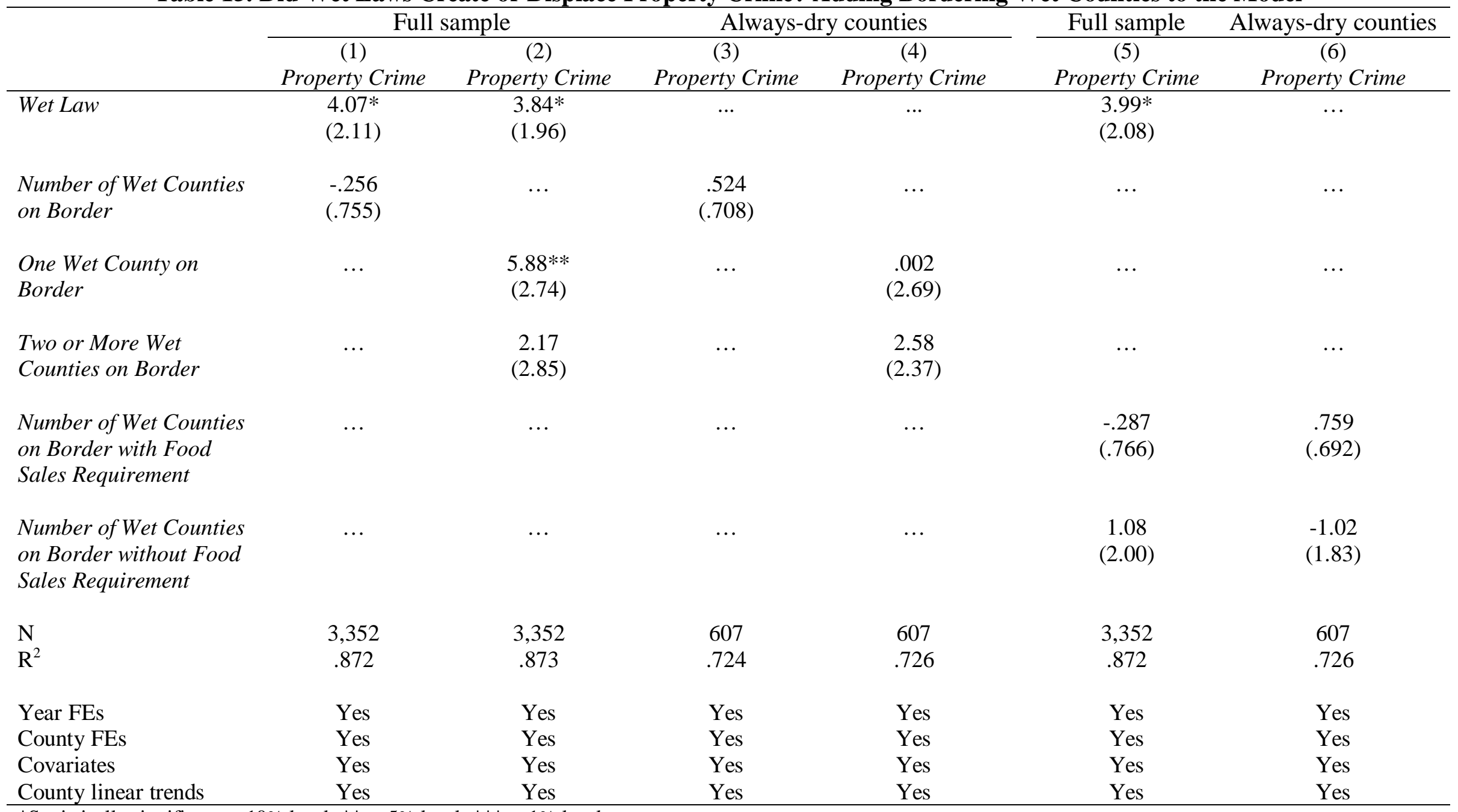

*Statistically significant at $10 \%$ level; ** at $5 \%$ level; *** at $1 \%$ level.

Notes: Each column represents the results from a separate OLS regression. The dependent variable is equal to the number of property crimes per 1,000 population in county $c$ and year $t$. The years 1995, 1996, and 1999 are excluded because of missing crime data. A list of covariates is provided in Table 2 . Regressions are weighted by county population and standard errors are corrected for clustering at the county level. 
Appendix Figure 1. Kansas Wet Laws, 1977-2011

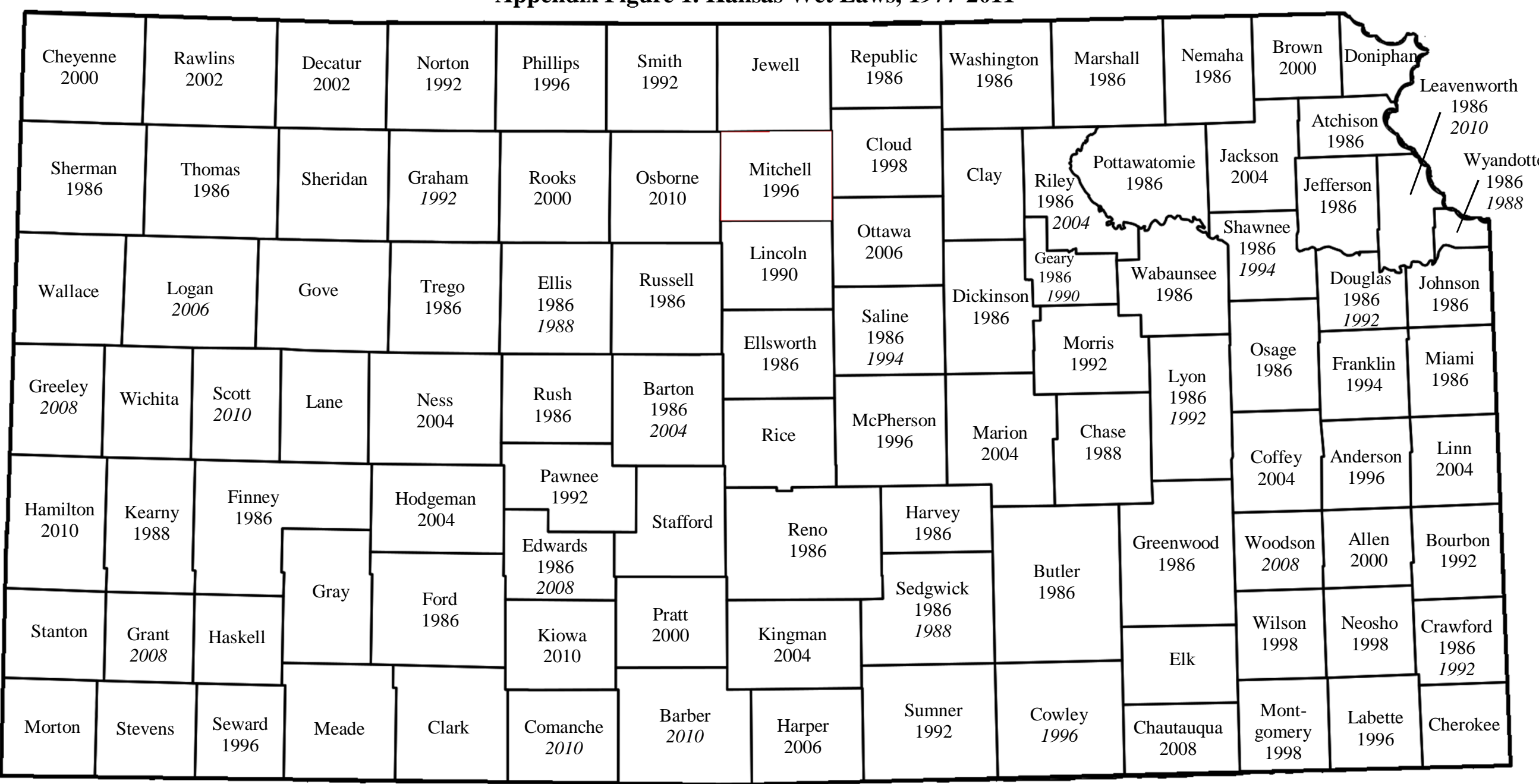

Note: The year below each county name denotes when on-premises alcohol consumption was voted into law. Italicized print indicates that on-premises consumption was allowed without requiring food sales. 


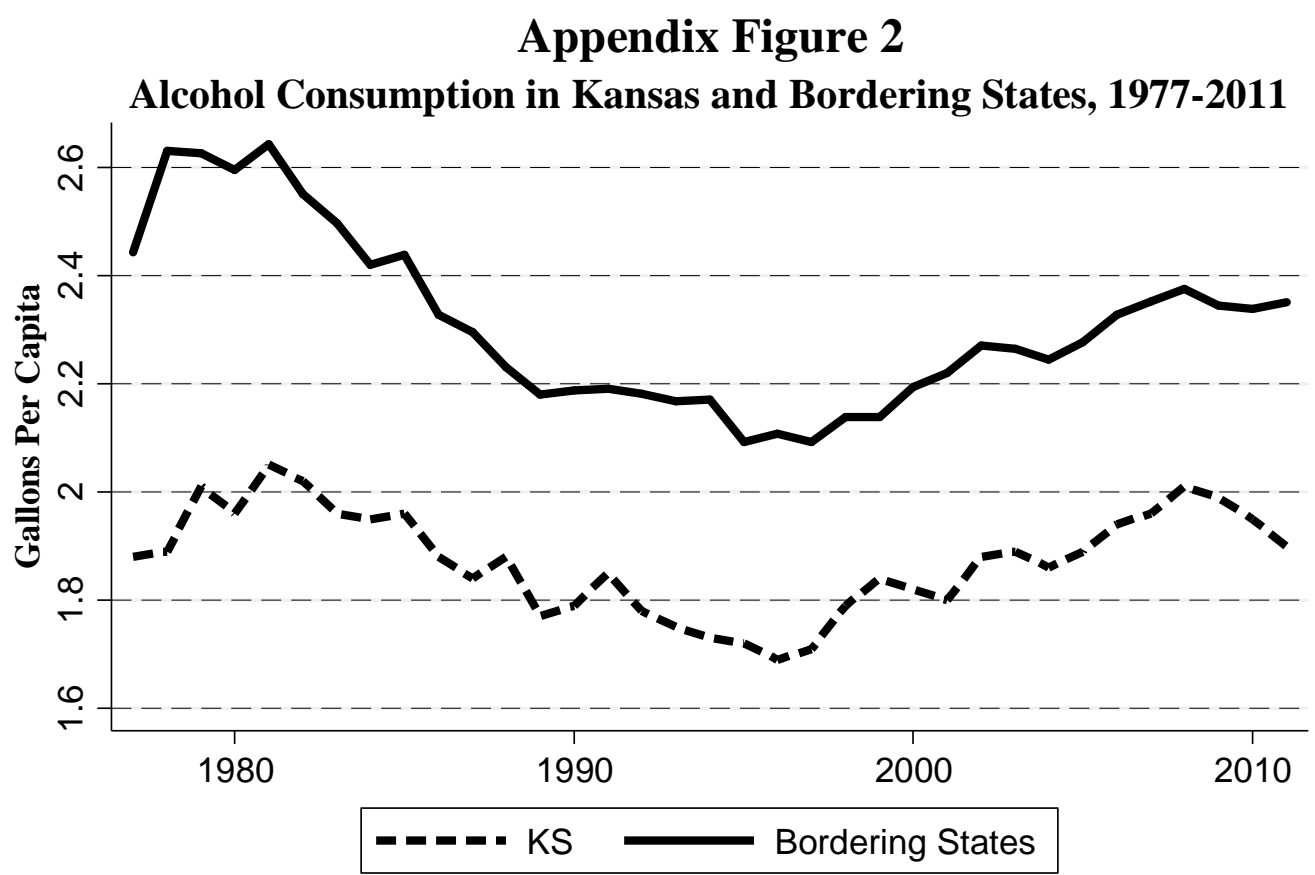

Note: Data on alcohol consumption are from the National Institute on Alcohol Abuse and Alcoholism. 
Appendix Table 1. Wet Laws and Off-Premises Alcohol Licenses, 1977-2011

\begin{tabular}{lcc}
\hline & Off-Premises Licenses & Off-Premises Licenses \\
\hline Wet Law & -.024 & .028 \\
& $(.030)$ & $(.018)$ \\
Mean of dependent variable & .525 & .525 \\
$\mathrm{~N}$ & 3,352 & 3,352 \\
$\mathrm{R}^{2}$ & .867 & .968 \\
& & \\
Year FEs & Yes & Yes \\
County FEs & Yes & Yes \\
Covariates & Yes & Yes \\
County linear trends & No & Yes \\
\hline
\end{tabular}

*Statistically significant at $10 \%$ level; ** at $5 \%$ level; *** at $1 \%$ level.

Notes: Each column represents the results from a separate OLS regression. The dependent variable is equal to the number of active off-premises alcohol licenses per 1,000 population in county $c$ and year $t$. The years 1995, 1996, and 1999 are excluded because of missing crime data. A list of covariates is provided in Table 2 . Regressions are weighted by county population and standard errors are corrected for clustering at the county level. 


\begin{tabular}{|c|c|c|c|}
\hline & $\begin{array}{c}\text { Full sample } \\
\text { Mean } \\
\text { (SD) }\end{array}$ & $\begin{array}{c}\text { Wet } L a w=1 \\
\text { Mean } \\
(\mathrm{SD})\end{array}$ & $\begin{array}{c}\text { Wet } L a w=0 \\
\text { Mean } \\
(\mathrm{SD})\end{array}$ \\
\hline Violent Crime & $\begin{array}{c}3.73 \\
(2.89)\end{array}$ & $\begin{array}{c}4.16 \\
(2.80)\end{array}$ & $\begin{array}{c}3.12 \\
(2.92)\end{array}$ \\
\hline Murder & $\begin{array}{l}.046 \\
(.060)\end{array}$ & $\begin{array}{l}.044 \\
(.059)\end{array}$ & $\begin{array}{l}.049 \\
(.062)\end{array}$ \\
\hline Rape & $\begin{array}{l}.349 \\
(.252)\end{array}$ & $\begin{array}{l}.413 \\
(.231)\end{array}$ & $\begin{array}{l}.257 \\
(.252)\end{array}$ \\
\hline Robbery & $\begin{array}{c}.811 \\
(1.05)\end{array}$ & $\begin{array}{c}.847 \\
(1.04)\end{array}$ & $\begin{array}{c}.760 \\
(1.06)\end{array}$ \\
\hline Assault & $\begin{array}{c}2.53 \\
(1.80)\end{array}$ & $\begin{array}{c}2.86 \\
(1.76)\end{array}$ & $\begin{array}{c}2.05 \\
(1.75)\end{array}$ \\
\hline Property Crime & $\begin{array}{c}39.9 \\
(21.2)\end{array}$ & $\begin{array}{c}40.2 \\
(19.9)\end{array}$ & $\begin{array}{c}39.6 \\
(23.1)\end{array}$ \\
\hline Burglary & $\begin{array}{c}9.80 \\
(6.52)\end{array}$ & $\begin{array}{c}8.69 \\
(5.54)\end{array}$ & $\begin{array}{c}11.4 \\
(7.43)\end{array}$ \\
\hline Larceny & $\begin{array}{c}27.6 \\
(13.9)\end{array}$ & $\begin{array}{c}28.6 \\
(13.1)\end{array}$ & $\begin{array}{c}26.1 \\
(14.8)\end{array}$ \\
\hline Motor Vehicle Theft & $\begin{array}{c}2.57 \\
(2.53)\end{array}$ & $\begin{array}{c}2.89 \\
(2.86)\end{array}$ & $\begin{array}{c}2.11 \\
(1.87)\end{array}$ \\
\hline $\mathrm{N}$ & 2,932 & 1,089 & 1,843 \\
\hline
\end{tabular}

Note: Information on crimes by type is unavailable for the years 1993-1999. Means are weighted by county population and standard deviations are shown in parentheses. All variables are reported as rates per 1,000 population. 
Appendix Table 3. Robustness Checks, Property Crime

\begin{tabular}{|c|c|c|c|c|c|c|c|}
\hline & $\begin{array}{l}\text { Placebo } \\
\text { Wet Law }\end{array}$ & $\begin{array}{c}\text { Restrict to } \\
\text { counties with } \\
\text { population }> \\
5,000\end{array}$ & $\begin{array}{c}\text { Restrict to } \\
\text { counties with } \\
\text { population }> \\
10,000\end{array}$ & $\begin{array}{c}\text { Control for } \\
\text { county-specific } \\
\text { quadratic time } \\
\text { trends }\end{array}$ & $\begin{array}{l}\text { Control for } \\
\text { crack epidemic }\end{array}$ & $\begin{array}{c}\text { Dependent } \\
\text { variable }= \\
\ln (\text { Property } \\
\text { Crime })\end{array}$ & $\begin{array}{l}\text { Negative } \\
\text { binomial }\end{array}$ \\
\hline & (1) & $(2)$ & $(3)$ & $(4)$ & $(5)$ & $(6)$ & $(7)$ \\
\hline & Property & Property & Property & Property & Property & Property & Property \\
\hline & Crime & Crime & Crime & Crime & Crime & Crime & Crime \\
\hline Average placebo Wet Law estimate & -.141 & $\ldots$ & $\ldots$ & $\ldots$ & $\ldots$ & $\ldots$ & $\ldots$ \\
\hline Wet Law & $\ldots$ & $\begin{array}{l}3.57^{*} \\
(1.97)\end{array}$ & $\begin{array}{c}3.29 \\
(2.56)\end{array}$ & $\begin{array}{l}5.25 * * \\
(2.21)\end{array}$ & $\begin{array}{l}4.50 * * \\
(2.15)\end{array}$ & $\begin{array}{l}.102 * \\
(.052)\end{array}$ & $\begin{array}{l}.091 * * \\
(.043)\end{array}$ \\
\hline $\mathrm{N}$ & 3,352 & 2,299 & 1,366 & 3,352 & 3,352 & 3,352 & 3,352 \\
\hline Number of trials & 100 & $\ldots$ & $\ldots$ & $\ldots$ & $\cdots$ & $\ldots$ & $\ldots$ \\
\hline Placebo coefficient $>0$ & 50 & $\ldots$ & $\ldots$ & $\cdots$ & $\cdots$ & $\cdots$ & $\cdots$ \\
\hline $\begin{array}{l}\text { Placebo coefficient }>0 \text { and significant } \\
\text { at } 5 \% \text { level }\end{array}$ & 4 & $\ldots$ & ... & $\ldots$ & $\ldots$ & $\ldots$ & $\cdots$ \\
\hline Year FEs & Yes & Yes & Yes & Yes & Yes & Yes & Yes \\
\hline County FEs & Yes & Yes & Yes & Yes & Yes & Yes & Yes \\
\hline Covariates & Yes & Yes & Yes & Yes & Yes & Yes & Yes \\
\hline County linear trends & Yes & Yes & Yes & Yes & Yes & Yes & Yes \\
\hline
\end{tabular}

*Statistically significant at $10 \%$ level; ** at $5 \%$ level; *** at $1 \%$ level.

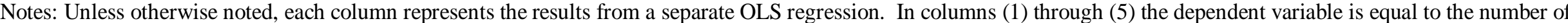

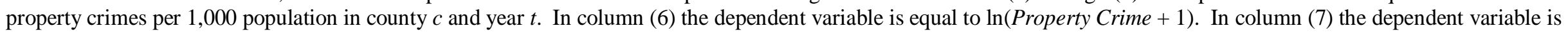

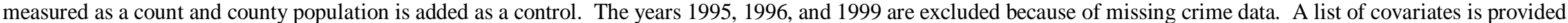
in Table 2. Regressions are weighted by county population and standard errors are corrected for clustering at the county level. 
Appendix Table 4. On-Premises Licenses and Property Crime by Crime Type, 1977-2011

\begin{tabular}{|c|c|c|c|c|c|c|c|c|}
\hline & $\begin{array}{c}\text { Property } \\
\text { Crime }\end{array}$ & $\begin{array}{c}\text { Property } \\
\text { Crime }\end{array}$ & Burglary & Burglary & Larceny & Larceny & $\begin{array}{c}\text { Motor } \\
\text { Vehicle } \\
\text { Theft }\end{array}$ & $\begin{array}{c}\text { Motor } \\
\text { Vehicle } \\
\text { Theft }\end{array}$ \\
\hline On-Premises Licenses & $\begin{array}{c}16.6 \\
(10.5)\end{array}$ & $\begin{array}{c}33.0 * * * \\
(12.4)\end{array}$ & $\begin{array}{c}1.38 \\
(3.82)\end{array}$ & $\begin{array}{c}5.62 \\
(4.45)\end{array}$ & $\begin{array}{l}12.0 * \\
(6.31)\end{array}$ & $\begin{array}{c}21.9 * * * \\
(7.71)\end{array}$ & $\begin{array}{c}3.20 * * \\
(1.59)\end{array}$ & $\begin{array}{l}5.52 * * \\
(2.37)\end{array}$ \\
\hline $\mathrm{N}$ & 2,932 & 2,932 & 2,932 & 2,932 & 2,932 & 2,932 & 2,932 & 2,932 \\
\hline $\mathrm{R}^{2}$ & .828 & .862 & .834 & .884 & .818 & .852 & .711 & .736 \\
\hline F-test of instrument & 54.2 & 42.6 & 54.2 & 42.6 & 54.2 & 42.6 & 54.2 & 42.6 \\
\hline Year FEs & Yes & Yes & Yes & Yes & Yes & Yes & Yes & Yes \\
\hline County FEs & Yes & Yes & Yes & Yes & Yes & Yes & Yes & Yes \\
\hline Covariates & Yes & Yes & Yes & Yes & Yes & Yes & Yes & Yes \\
\hline County linear trends & No & Yes & No & Yes & No & Yes & No & Yes \\
\hline
\end{tabular}

*Statistically significant at $10 \%$ level; ** at $5 \%$ level; *** at $1 \%$ level.

Notes: Each column represents the results from a separate 2SLS regression. Crime in county $c$ and year $t$ is measured per 1,000 population. The years 1993-1999 are excluded because of missing crime data. A list of covariates is provided in Table 2 and means of property crimes by type are provided in Appendix Table 2. Regressions are weighted by county population and standard errors are corrected for clustering at the county level. 